\title{
Traditions of Jars as Mortuary Containers in the Indo-Malaysian Archipelago
}

\author{
David Bulbeck
}

\begin{abstract}
Earthenware and imported ceramic jars were from time to time used as mortuary containers across a large swathe of the Indo-Malaysian Archipelago. As noted by Peter Bellwood, this deployment of earthenwares has Neolithic origins, and burgeoned during approximately the first millennium AD. The assemblages were frequently dominated by disposals in mortuary jars but these were one of a variety of mortuary practices at other sites. Defining a jar-burial tradition as a potentially independent development of the use of jars as mortuary containers, we may provisionally identify 14 geographically discrete jar-burial traditions within the archipelago.
\end{abstract}

\section{Introduction}

In his textbook on the prehistory of the Indo-Malaysian Archipelago, Peter Bellwood (1997) dealt at length with the use of jars as mortuary containers, which he assigned to a tradition best regarded 'as an indigenous development in Island Southeast Asia' (p. 306). He traced the tradition's origins to late Neolithic contexts, noting, however, that many more sites date to the Palaeometallic or Early Metal Phase. He also stated that the recorded sites appeared to be particularly a feature of the triangular area in between the Philippines, Borneo and Sumba (p. 296). Implicitly, Bellwood referred to the use of jars not as grave goods but as mortuary containers, even if this specific use of the recovered pottery is inferred rather than directly observed at certain sites, such as Leang Buidane (see below). The examples he discussed also exclude sites with jars buried for rituals that were probably non-mortuary, considering the lack of associated human remains in conditions that should be conducive to preservation of bone - for instance, the Palaeometallic jars buried at Makabog in the Philippines (Henson 1992), Leang Balangingi in the Talaud Islands (Bellwood 1976) and Batu Ejaya in southwest Sulawesi (Bulbeck 1996-1997).

In this review of the sites covered by Bellwood (1997) as well as more recently documented sites, I shall summarise the evidence in broad support of Bellwood's chronology. However, the area with a concentrated use of jars as mortuary containers can now be revised as the trapezoidal belt of islands from the Philippines in the north to southern Sumatra in the southwest and Sumba and the Moluccas in the southeast (Figure 8.1). In addition, I shall propose that the mourners' choice of jars rather than some other container, or indeed the disposal of container-free mortuary remains, cannot be related in any simple way to socioeconomic factors or reconstructible belief systems. 


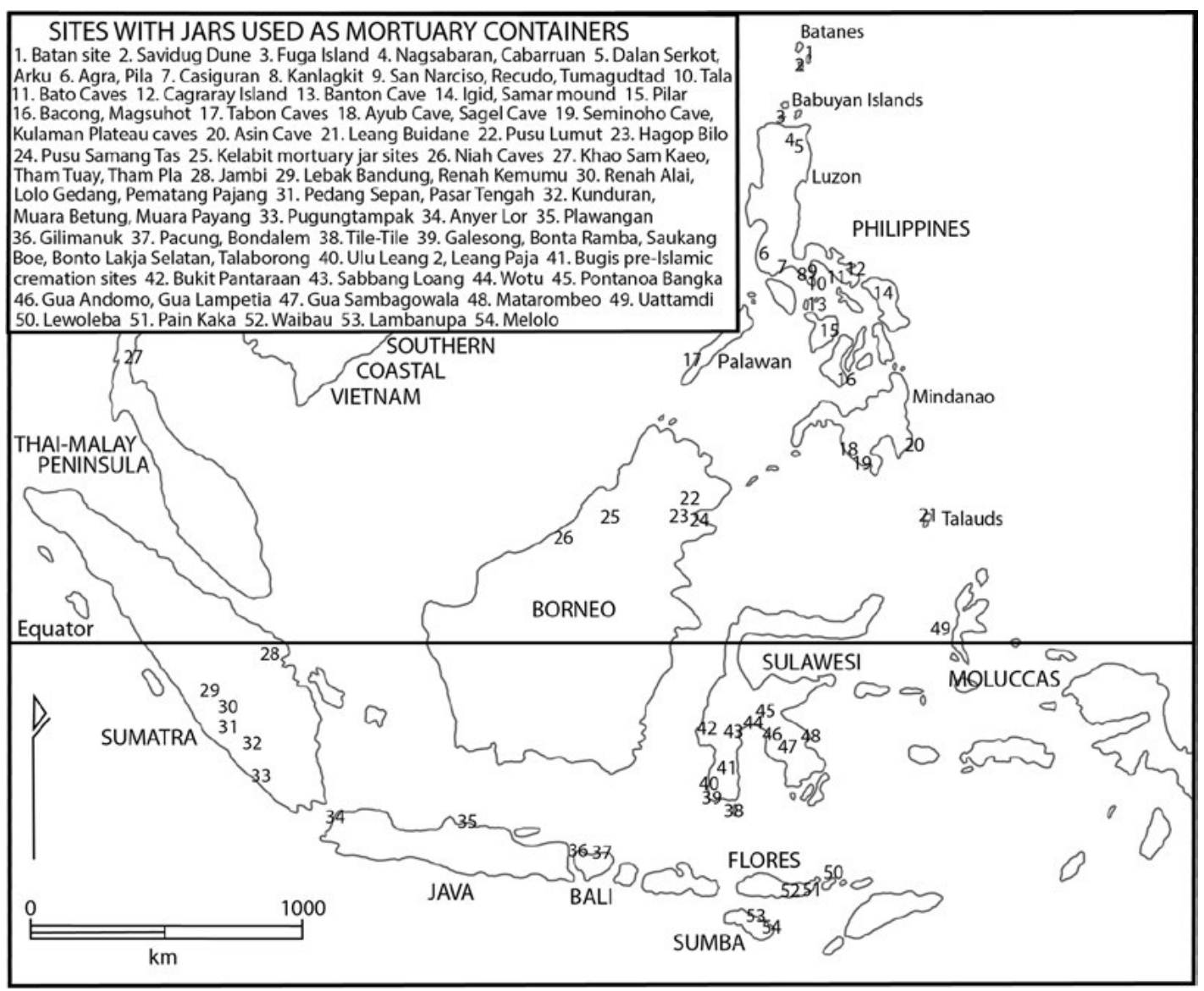

Figure 8.1 Sites in the Indo-Malaysian Archipelago with jars used as mortuary containers.

Source: Compiled and drawn by D. Bulbeck.

On the question of whether jar burials in the Indo-Malaysian Archipelago should be assigned to a single (Bellwood 1997) or multiple traditions (Lloyd-Smith and Cole 2010), we should first define the term 'tradition'. According to Fagan (1994: 420), the term implies cultural continuity of the subject of the tradition (such as an artefact type) over lengthy periods of time by cultures that may vary in other ways. Valentin et al. (2015) interpret the concept of a single IndoMalaysian jar-burial tradition to mean a single shared belief system on issues related to handling the deceased. However, in terms of Fagan's definition, all that would be required is continuity of jar burials as a practice tracing back to its original source. This source would be Neolithic Taiwan, where jar burials date back to at least $1000 \mathrm{cal}$. BC; and its transmission to Indo-Malaysia would have been undertaken by the southward expansion of early Austronesian (Malayo-Polynesian) speakers, according to Valentin et al. (2015) as well as Bellwood (as reported by Cuevas and de Leon 2008: 19). Thus, despite their explicit support for multiple traditions in Indo-Malaysia, and a separate but related tradition at Teouma in Vanuatu, Valentin et al. (2015) actually endorse a single tradition. This may also be the same tradition that resulted in jar burials postdating Teouma (and mostly dating to the second millennium AD) in various other Pacific Islands where Austronesian languages were spoken ethnographically or the inhabitants were in contact with Austronesian speakers (Bedford and Spriggs 2007). 
Instead, the touchstone for recognising multiple traditions would be to show that one or more independent developments of the practice of jar burials is a more reasonable scenario than continuity of the original practice. In addition, if multiple independent developments of jar burials appears likely, then geographical proximity of sites with a similar range of jar-burial practices would provide the empirical grounds to be confident in assigning these sites to a single tradition. On that basis, as detailed below, 14 traditions could be posited to cover the diversity documented across the archipelago.

The concept of 'horizon', which may be used to 'link a number of phases in neighboring areas that have rather general cultural patterns in common' (Fagan 1994: 420), is also useful for reviewing the archaeological evidence. A horizon could mark the appearance of a new jar-burial tradition(s) or it could signify the shared transformation of previously established jar-burial traditions.

The broad chronological scheme for Indo-Malaysian prehistory outlined by Bellwood (1997) is employed here, with the Neolithic (defined by the appearance of pottery and polished stone tools) dating to between $c a .2000$ and $200 \mathrm{cal}$. BC, and the Palaeometallic to approximately the first millennium $\mathrm{AD}$. The latter largely corresponds to the early appearance of metals and exotic items of glass and semi-precious stone, but the date of their earliest appearance varied across the archipelago. Accordingly, their absence from an assemblage is no guarantee that the assemblage predates $200 \mathrm{BC}$, particularly if it is not large.

\section{Neolithic foundations}

\section{Niah Caves}

The oldest intact jar burials in the archipelago were excavated in the Neolithic cemeteries at the Niah Caves, predominantly the West Mouth but also several from the smaller Lobang Jeragan cemetery (Table 8.1). The term 'Neolithic' is qualified by the occurrence of three small bronze items amongst the sparse assemblage of grave goods, two inside jar burials and the third found with an extended burial. Dating all three bronzes to earlier than $500 \mathrm{cal}$. BC - making them the archipelago's oldest dated bronzes - is conservative in view of the 1500-1414 cal. BC and $812-559$ cal. BC determinations on the two dated burials with bronze (Lloyd-Smith et al. 2013). Moreover, the appearance of bronze - undocumented for Taiwan sites of this antiquity (Valentin et al. 2015) - raises a legitimate question of whether the source for the Niah jar burials should be traced to Mainland Southeast Asia, where sites such as Ban Non Wat, Ban Lum Khao and Nong Nor included jar burials by the second millennium BC and bronze by the end of the millennium (Bulbeck 2011; Higham 2011).

All of the Niah burial jars were at least partially interred, with full burial noted for three of the 12 West Mouth examples (Lloyd-Smith and Cole 2010). The Niah Caves jar burials are notable for their sparse occurrence (some 5-10 per cent of burials) over a long period of time between $c a$. 1150 and 300 cal. BC (Lloyd-Smith et al. 2013). They are remarkable for their diversity in terms of the nature of the jars used as containers, the treatment of the bone (variably cremated and/or haematite-stained), the interred individuals' demographics and whether single or multiple burials were interred (Table 8.1). Their sparseness and diversity suggest a recurrent practice 'reinstantiated' to meet particular ritual needs, with the use of the jars - rather than one of the other Niah burial modes (Table 8.2) - as a marker of attained wealth and social status (Lloyd-Smith and Cole 2010). Significantly, another Niah cemetery, Gan Kira, had no jar burials for either its Neolithic or its Palaeometallic stage (Szabó et al. 2013). 


\begin{tabular}{|c|c|c|c|c|c|c|c|c|c|c|c|c|c|}
\hline$\cong$ & 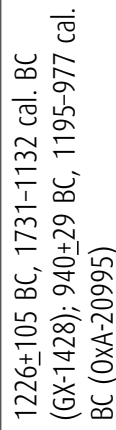 & 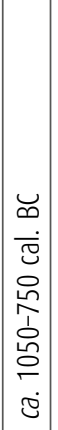 & 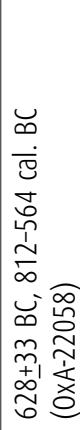 & 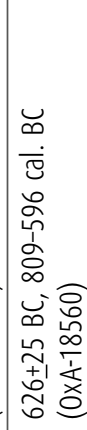 & 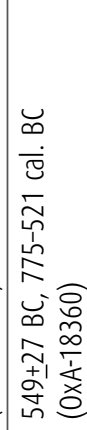 & 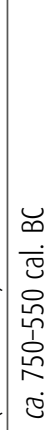 & 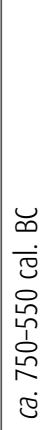 & 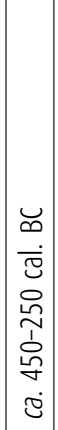 & 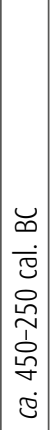 & 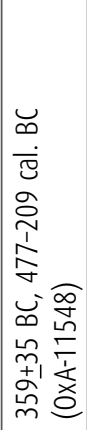 & 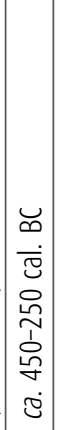 & 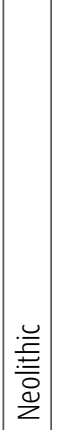 & 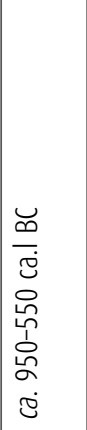 \\
\hline 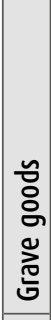 & 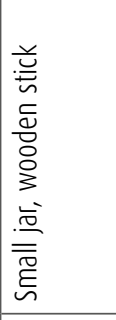 & $\begin{array}{l}0 \\
\text { Oे } \\
2\end{array}$ & 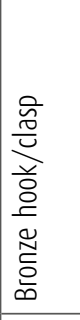 & 䒓 & 苾 & 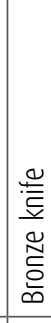 & 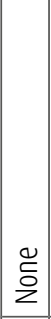 & $\begin{array}{l}\text { 蒿 } \\
\text { | }\end{array}$ & 产 & 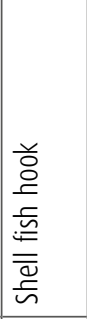 & 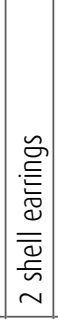 & $\mid \begin{array}{l}0 \\
\tilde{2} \\
z\end{array}$ & 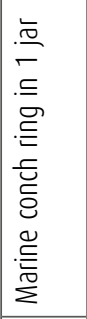 \\
\hline 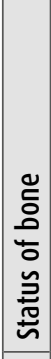 & 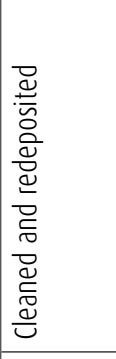 & 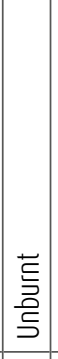 & 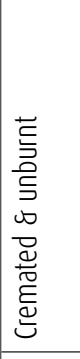 & 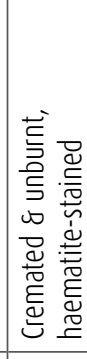 & 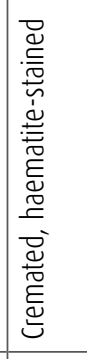 & 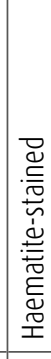 & 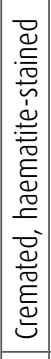 & 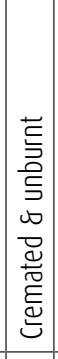 & 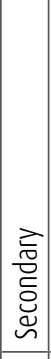 & $\begin{array}{l}\text { 롣 } \\
\text { 产 } \\
\text { S }\end{array}$ & 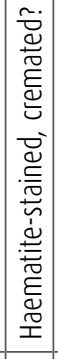 & 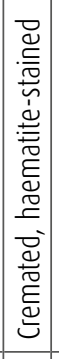 & 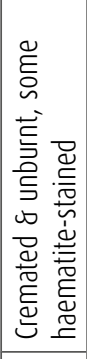 \\
\hline 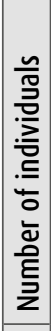 & 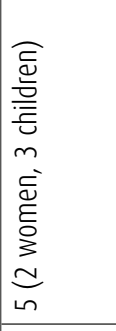 & 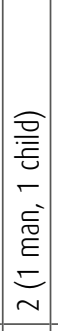 & $\begin{array}{l}\frac{n}{7} \\
\stackrel{0}{0} \\
\sim\end{array}$ & 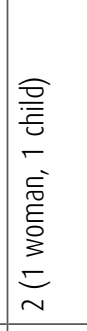 & 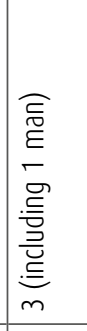 & $\begin{array}{l}\text { 言 } \\
\text { ㅁ } \\
\end{array}$ & \begin{tabular}{|l} 
\\
$\bar{\Xi}$ \\
$\stackrel{0}{\sigma}$ \\
\end{tabular} & 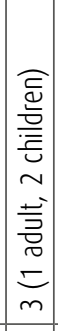 & 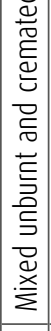 & 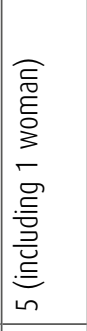 & 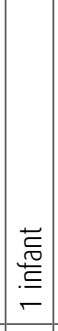 & - & 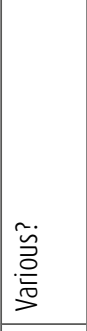 \\
\hline 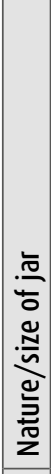 & 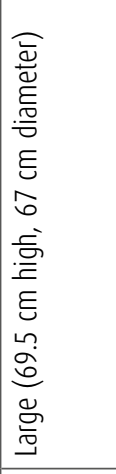 & 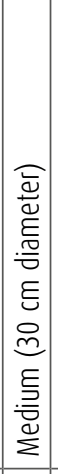 & 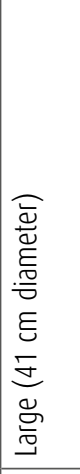 & 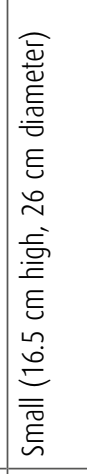 & 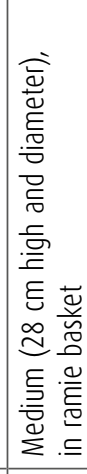 & 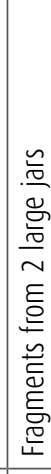 & 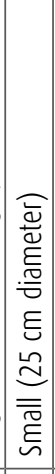 & 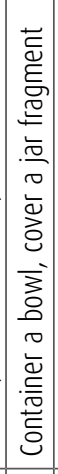 & 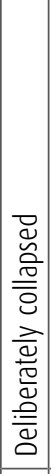 & 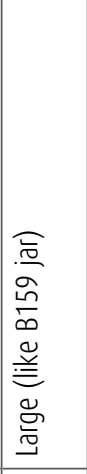 & 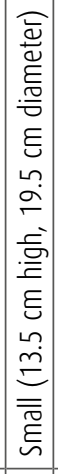 & 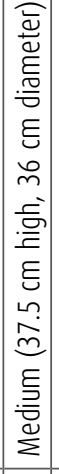 & $\begin{array}{l}\text { בे } \\
\text { 高 } \\
\end{array}$ \\
\hline 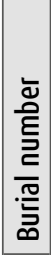 & 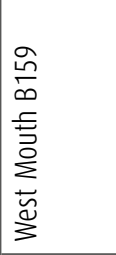 & 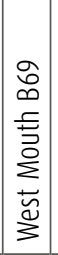 & 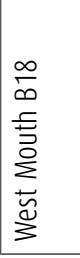 & 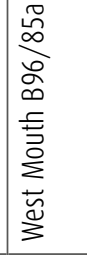 & 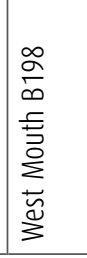 & 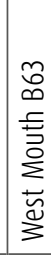 & 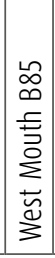 & 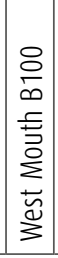 & 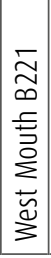 & 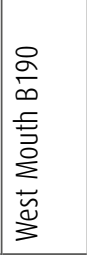 & 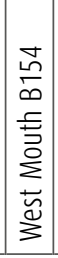 & 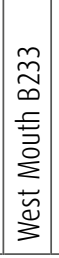 & 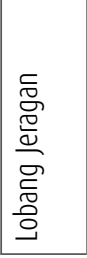 \\
\hline
\end{tabular}




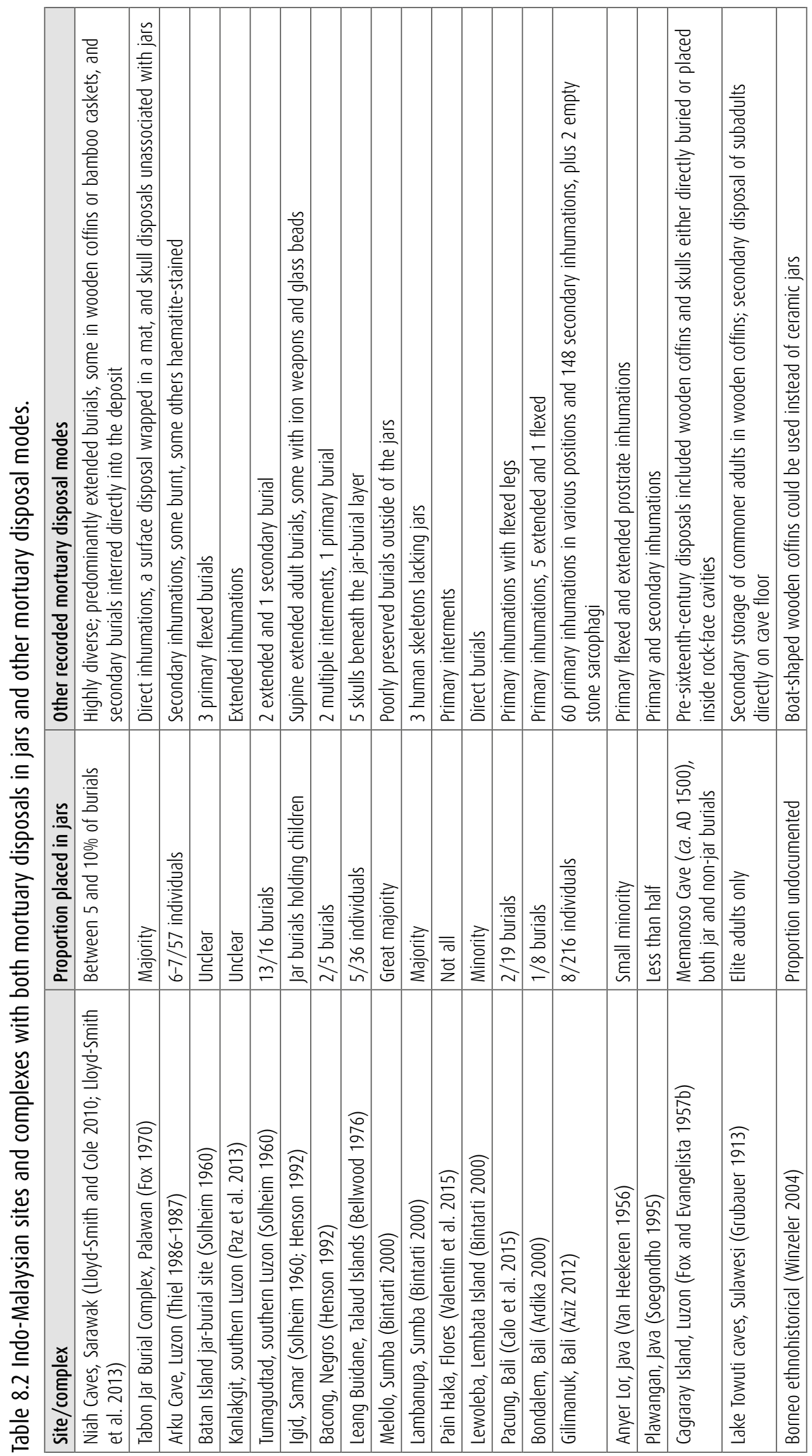




\section{The Philippines}

Several Philippine sites have yielded Neolithic jar burials although a larger number date to the Palaeometallic. Their coverage presented here should be considered in the context of the Neolithic and Palaeometallic Philippine burials that did not involve mortuary jars, including Callao Cave (Mijares 2005) and some of the Lal-lo shell middens (Ogawa 2004) in Luzon, and Sa'gung (Kress 2004), Ille Cave (Szabó et al. 2004) and Leta Leta (Szabó and Ramirez 2009) in Palawan. The Neolithic grave goods, in particular, show strong parallels with Taiwan Neolithic material culture (Valentin et al. 2015).

Table 8.3 Dates for Philippine mortuary jar sites.

\begin{tabular}{|c|c|c|}
\hline Site & Summary description of mortuary jars & Dating \\
\hline Dalan Serkot (Mijares 2005) & $\begin{array}{l}\text { Thick jar sherds associated with fragmentary human } \\
\text { remains }\end{array}$ & $\begin{array}{l}\text { 1581+34 BC (Wk-15648), } \\
\text { 1947-1753 cal. BC }\end{array}$ \\
\hline $\begin{array}{l}\text { Manunggul A, near Tabon } \\
\text { (Fox 1970) }\end{array}$ & $\begin{array}{l}\text { Frequently decorated, medium-sized jars containing } \\
\text { secondary disposals; grave goods (including pots and } \\
\text { nephrite, agate and shell jewellery) placed inside or } \\
\text { near the jars }\end{array}$ & $\begin{array}{l}891 \pm 80 \text { BC (UCLA-992A), } \\
1222-827 \text { cal. BC } \\
711 \pm 80 \text { BC (UCLA-992B), } \\
1014-544 \text { cal. BC }\end{array}$ \\
\hline Manunggul B (Fox 1970) & $\begin{array}{l}\text { Plain medium-sized jars containing secondary disposals; } \\
\text { grave goods now including iron, carnelian and glass } \\
\text { jewellery }\end{array}$ & $\begin{array}{l}\text { 191_100 BC (UCLA-992C), } \\
396 \text { cal. BC-cal. AD } 49\end{array}$ \\
\hline $\begin{array}{l}\text { Arku Cave, Luzon } \\
\text { (Thiel 1986-1987) }\end{array}$ & $\begin{array}{l}4 \text { small to medium-sized jars containing secondary } \\
\text { disposals, some burnt, some others haematite-stained; } \\
\text { grave goods within jars include a small jar and ochre }\end{array}$ & $\begin{array}{l}471+80 \text { BC (ISGS-495), 780-405 } \\
\text { cal. BC }\end{array}$ \\
\hline $\begin{array}{l}\text { Bato Cave 1, Luzon } \\
\text { (Fox and Evangelista } \\
\text { 1957a) }\end{array}$ & $\begin{array}{l}\text { Large to medium-sized jars containing secondary } \\
\text { disposals; grave goods of shell and indurated shale, } \\
1 \text { polished stone axe }\end{array}$ & $\begin{array}{l}331 \pm 250 \text { BC (M-727A) on marine } \\
\text { shell (Crane and Griffin 1959), } \\
694 \text { cal. BC-cal. AD } 546\end{array}$ \\
\hline $\begin{array}{l}\text { Nagsabaran, Luzon } \\
\text { (Piper et al. 2009) }\end{array}$ & $\begin{array}{l}\text { Medium-sized jars containing crania, perhaps removed } \\
\text { from flexed inhumations; associated with glass and iron }\end{array}$ & $\begin{array}{l}150 \text { cal. BC-cal. AD } 450 \text { (multiple } \\
\text { dates) for the midden deposit } \\
\text { containing the burials }\end{array}$ \\
\hline $\begin{array}{l}\text { Ayub Cave, Mindanao } \\
\text { (Bacus 2004) }\end{array}$ & $\begin{array}{l}\text { 100-200 large jars (some anthropomorphic, some others } \\
\text { also decorated) with secondary disposals and grave } \\
\text { goods such as decorated small jars, and ornaments } \\
\text { of earthenware, shell and glass }\end{array}$ & $\begin{array}{l}\text { AD 30+50 (Beta-83316), } 38 \text { cal. } \\
\text { BC-cal. AD } 217 \\
\text { AD 120 } 160 \text { (Beta-83315), } \\
\text { cal. AD 55-339 (Ronquillo 2003) }\end{array}$ \\
\hline $\begin{array}{l}\text { Savidug Dune, Batanes } \\
\text { (Bellwood and Dizon } \\
\text { 2013a) }\end{array}$ & Large jars probably containing flexed primary burials & $\begin{array}{l}\text { AD 195+25 (ANU 33938), cal. AD } \\
222-378\end{array}$ \\
\hline $\begin{array}{l}\text { Seminoho Cave, Mindanao } \\
\text { (Cuevas and de Leon 2008) }\end{array}$ & $\begin{array}{l}\text { Large jars (some anthropomorphic, some others also } \\
\text { decorated) holding secondary disposals and grave goods } \\
\text { such as small jars, carnelian beads, and ornaments } \\
\text { of earthenware, shell, brass and iron }\end{array}$ & $\begin{array}{l}\text { AD } 585+85 \text { on human bone, } \\
\text { cal. AD } 436-882\end{array}$ \\
\hline $\begin{array}{l}\text { Banton Cave, Visayas } \\
\text { (Barnes and Kahlenburg } \\
\text { 2010) }\end{array}$ & $\begin{array}{l}\text { Medium-sized jar containing human remains wrapped } \\
\text { in Indian textile }\end{array}$ & $\begin{array}{l}\text { Thirteenth-century AD on human } \\
\text { bone }\end{array}$ \\
\hline Pilar, Panay (Anon. 2009) & $\begin{array}{l}24 \text { jar burials containing clay, glass beads and iron } \\
\text { spearhead }\end{array}$ & $\begin{array}{l}\text { AD 1460+180 (Coutts 1983), } \\
\text { cal. AD 1161-1950 }\end{array}$ \\
\hline
\end{tabular}

Source: Calibrations (95.4 per cent confidence interval) undertaken by the author using 0xcal 4.2 (Bronk Ramsey 2014).

The antiquity of jar burials in the Philippines may reach back to the beginnings of the Neolithic, if Mijares (2005) is correct in his interpretation of Dalan Serkot as a cave for the secondary burial of the deceased in mortuary jars, dated to the early second millennium BC (Table 8.3). Arku Cave, near Dalan Serkot, produced a rich, late Neolithic mortuary assemblage dated to approximately 1300-1 cal. BC (Spriggs 1989), with grave goods that included jewellery of 
shell, fired clay, nephrite and other stone, as well as polished stone adzes, bone points, tattooing chisels of horn and clay spindle whorls (Thiel 1986-1987). About one-ninth of the represented individuals can be clearly identified as jar burials, distinguished from the other burials by the modest quality of the grave goods (Tables 8.2 and 8.3). Jar burials at Arku Cave, then, would appear to have been reserved for a residue of individuals of low socioeconomic status, unless the act of burial within a jar signified an elevated status in itself.

Fox (1970; Winters 1974) nominated the term 'Tabon Jar Burial Complex' for the 29 Palawan sites with mortuary ceramics near Tabon Cave. The jars had been placed on or within the cave surfaces, which rules out dating the jars with samples from cave deposits except where the cave had no other documented utilisation. There are three such dates, on charcoal, which together indicate pre-metallic mortuary disposals in Manunggul Chamber A during the first half of the first millennium BC, and Palaeometallic mortuary disposals in Manunggul Chamber B during the last centuries BC (Table 8.3). Winters identified a minimum of 14-19 individuals from the human remains in the 20-30 burial jars at Duyong Cave, and 16 individuals from the Uyaw Cave human remains. His analysis confirms Fox's inference that the Tabon complex mortuary jars generally contained single individuals, including infants and one apparent primary child burial. Fox also noted that the human remains were sometimes painted with haematite, and that the jars sometimes contained just the skull or, in one case, the teeth of multiple individuals. The majority but not all of mortuary disposals were placed inside jars (Table 8.2).

\section{Palaeometallic mortuary-jar container sites (ca. $200 \mathrm{BC}$ to AD 1200)}

Most Palaeometallic jar-burial sites have been assigned to this period based on the nature of their grave goods, but in some cases the assignment relies on radiometric dating. For instance, on Sabtang Island at the far north of the Philippines, Bellwood and Dizon (2013a) uncovered a cluster of 14 large jars dating to the early centuries AD, but lacking any grave goods (Table 8.3). A similar antiquity may apply to the large jar burials excavated on nearby Batan Island, although the fact these jars were looted might suggest the original presence of grave goods (Solheim 1960). Also, the Bato Caves in Luzon produced 18 jar burials associated with Neolithic grave goods and no trace of metals (Fox and Evangelista 1957a), despite their dating to around the time of Christ based on the only associated radiocarbon date (Table 8.3).

Of possibly similar age is the 'Neolithic' pottery with 'Kalanay'-style painted and incised decorations at Asin Cave, southeastern Mindanao, suspected to date before Christ. Solheim et al. (1979) estimated the burial of about 20 large jars holding the skull and other human bones, probably secondarily disposed, in association with 80 bowls and small jars, and a stone jar cover. Similar stone covers are reported for the jar burials from Kanlagkit, San Narciso, Recudo and Tumagudtad, Luzon (Paz et al. 2013) and the burial jars containing juveniles at the open site of Igid, Samar (Henson 1992). The Igid extended burials and the Recudo and Tumagudtad jar burials were associated with iron implements and other Palaeometallic grave goods.

Other Philippine jar-burial sites with glass and/or metal grave goods include most of the secondary jar-burial sites on Cagraray Island in southern Luzon (Fox and Evangelista 1957b), the Casiguran and other northwest Sorsogan jar burials from southern Luzon, the 60 jar burials from a mound on Samar, and the Bacong jar burials on Negros (Henson 1992). At Magsuhot, near Bacong, two large burial jars containing glass and iron grave goods were excavated, one also holding the remains of an adult female and two subadults, along with three empty burial jars (Bacus 2004). The Nagsabaran jar burials in northern Luzon, dated to around 2,000 years ago, are of particular interest, in that they appear to have held the crania removed from the flexed inhumations in 
the same level (Piper et al. 2009). A similar practice of decapitating the corpse, with the skull sometimes stored inside a jar, appears to have been adopted at the Neolithic cemetery at Teouma in Vanuatu (Valentin et al. 2015).

Also of considerable interest are the large, anthropomorphic burial jars in southern Mindanao, dated to the first millennium AD at Ayub Cave and at Seminoho Cave (Table 8.3), one of the numerous such sites (more than 1,000 recorded mortuary jars) on the Kulaman Plateau. However, not all southern Mindanao jar-burial sites with Palaeometallic burial goods include anthropomorphic jars, as indicated by their absence from Sagel Cave, which lies near Ayub Cave (Cuevas and de Leon 2008).

To the south of Mindanao lie the Talaud Islands, where the Leang Buidane rockshelter yielded mortuary pottery and scattered human remains whose chronology is suspected to span much of the first millennium $\mathrm{AD}$. Interpretation of the excavated materials as a jar-burial assemblage is strengthened by the match between the minimum numbers of 36 interred individuals and 32 large jars. The rich assemblage of mortuary goods includes beads and bracelets of shell, semiprecious stone and glass, as well as bronze and iron, and three baked-clay casting moulds, one with a thermoluminescence date of AD 1000 \pm 130 (Bellwood 1976, 1997).

Three jar-burial assemblages of similar nature, age, pottery decorations and associated grave goods have also been excavated in southeastern Sabah, Borneo (Bellwood 1988a, 1988b, 1988c). Hagop Bilo yielded fragmentary human remains associated with iron fragments (including one from a bushknife) and decorated pottery with affinities to the Leang Buidane and Manunggul A pottery, to a depth of $15 \mathrm{~cm}$. Its estimated antiquity is AD 450-850. Pusu Lumut contained a $30 \mathrm{~cm}$ thick layer with pottery similar to the Hagop Bilo mortuary pottery and was associated with human fragments and a variety of grave goods, including small stone adzes, potterymaking burnishing stones or anvils, a socketed copper/bronze axe, an axe-casting valve, an iron spearhead and two stone or glass beads. The assemblage has a quite wide estimated age range (AD 450-1450). Pusu Samang Tas also contained a $30 \mathrm{~cm}$ thick sedimentary layer with fragmentary human remains associated with grave goods (five glass beads and two iron knives). Bellwood (1988c) estimates its age as AD 950-1450 based on the similarity of its mortuary pottery to Pusu Lumut and also to Pilar in the Visayas. Both Pusu Lumut and Pusu Samang Tas would overlap in age with the log coffin from the nearby site of Agop Atas, radiocarbon-dated to around AD 1000 (Bellwood 1988b).

Another similar site, according to Bellwood et al. (1998), is the Uattamdi rockshelter (Kayoa Island, North Moluccas) with jar burials associated with glass beads, iron and bronze fragments, dated to the first millennium AD. However, Uattamdi differs from the Sabah sites in that the only skeletal remains associated with its two massive jars are two human crania. Indeed, Uattamdi evidently combines a previously established tradition of secondary skull burials, recorded at the nearby site of Tanjung Pinang, with the locally derived 'invention' of using the jars as mortuary containers rather than grave furniture (Bulbeck submitted).

Five sites with jar burials, at least four also containing direct interments (Table 8.2), are recorded for Nusatenggara. Melolo is an extensive urn field with hundreds of large globular jars covered by a smaller upside-down pot, most containing just a single skull, but others containing skulls of multiple individuals and/or a few limb bones. The site is renowned for its burnished kendi flasks with incised human faces, interred as grave goods along with a range of shell ornaments, stone axes and beads, spindle whorls, glass items and bronze fragments (Van Heekeren 1972; Bintarti 2000). Bellwood (1997) interprets kendi flasks as a widely distributed Palaeometallic chronological marker, also recorded at Leang Buidane, Hagop Bilo, as well as Gunung Piring on Lombok and Liang Bua on Flores (where jar burials have not been documented), and Anyer Lor in Java (see below). 
Table 8.4 Open jar-burial sites from southern Sumatra.

\begin{tabular}{|c|c|c|}
\hline Site/s & Description & Dating evidence \\
\hline Jambi city (Bintarti 2000) & $\begin{array}{l}3 \text { urns, } 30.5 \mathrm{~cm} \text { high and } 24.5 \mathrm{~cm} \\
\text { mouth diameter }\end{array}$ & $\begin{array}{l}85 \text { beads including } 8 \text { Indo-Pacific orange } \\
\text { glass beads }\end{array}$ \\
\hline Lebak Bandung, Jambi (Bonatz et al. 2006) & Large jars & $\begin{array}{l}\text { Grave goods include glass beads } \\
\text { and iron knives }\end{array}$ \\
\hline $\begin{array}{l}\text { Renah Kemumu, Kerinci highlands } \\
\text { (Bonatz et al. 2006; Tjoa-Bonatz 2012) }\end{array}$ & $\begin{array}{l}35 \text { jars } 0.6-1.2 \text { m diameter, human } \\
\text { remains dissolved in acidic soil, } \\
\text { small pots as grave goods }\end{array}$ & 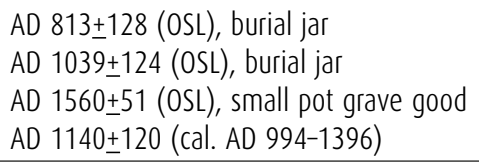 \\
\hline $\begin{array}{l}\text { Pematang Pajang, Renah Alai, unnamed } \\
\text { site-Kerinci highlands (Tjoa-Bonatz 2012) }\end{array}$ & At least 6 jars at Renah Alai & Information not found \\
\hline $\begin{array}{l}\text { Lolo Gedang, Kerinci highlands (Bonatz } \\
\text { 2012; Tjoa-Bonatz 2012) }\end{array}$ & $\begin{array}{l}\text { Large jars containing broken } \\
\text { bones, iron and bronzes including } \\
\text { miniature drums }\end{array}$ & 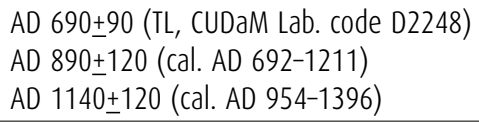 \\
\hline $\begin{array}{l}\text { Pedang Sepan, Pasar Tengah-Bengkulu } \\
\text { (Bonatz et al. 2006) }\end{array}$ & Information not found & Information not found \\
\hline $\begin{array}{l}\text { Kunduran, Muara Betung, Muara Payang- } \\
\text { Lintang, South Sumatra, 200-1,000 m asl } \\
\text { (Soeroso 1997; Guillaud et al. 2006) }\end{array}$ & $\begin{array}{l}\text { Large jars taking primary or } \\
\text { secondary burials }\end{array}$ & $\begin{array}{l}\text { Grave goods include a kendi flask at } \\
\text { Kunduran, metal fragments at Muara } \\
\text { Betung, and polished adzes of jasper } \\
\text { and chalcedony }\end{array}$ \\
\hline Pugungtampak, Lampung (Bintarti 2000) & No information & No information \\
\hline
\end{tabular}

Source: Calibration of radiocarbon dates (95.4 per cent confidence interval) undertaken by the author using $0 x c a l$ l.2 (Bronk Ramsey 2014).

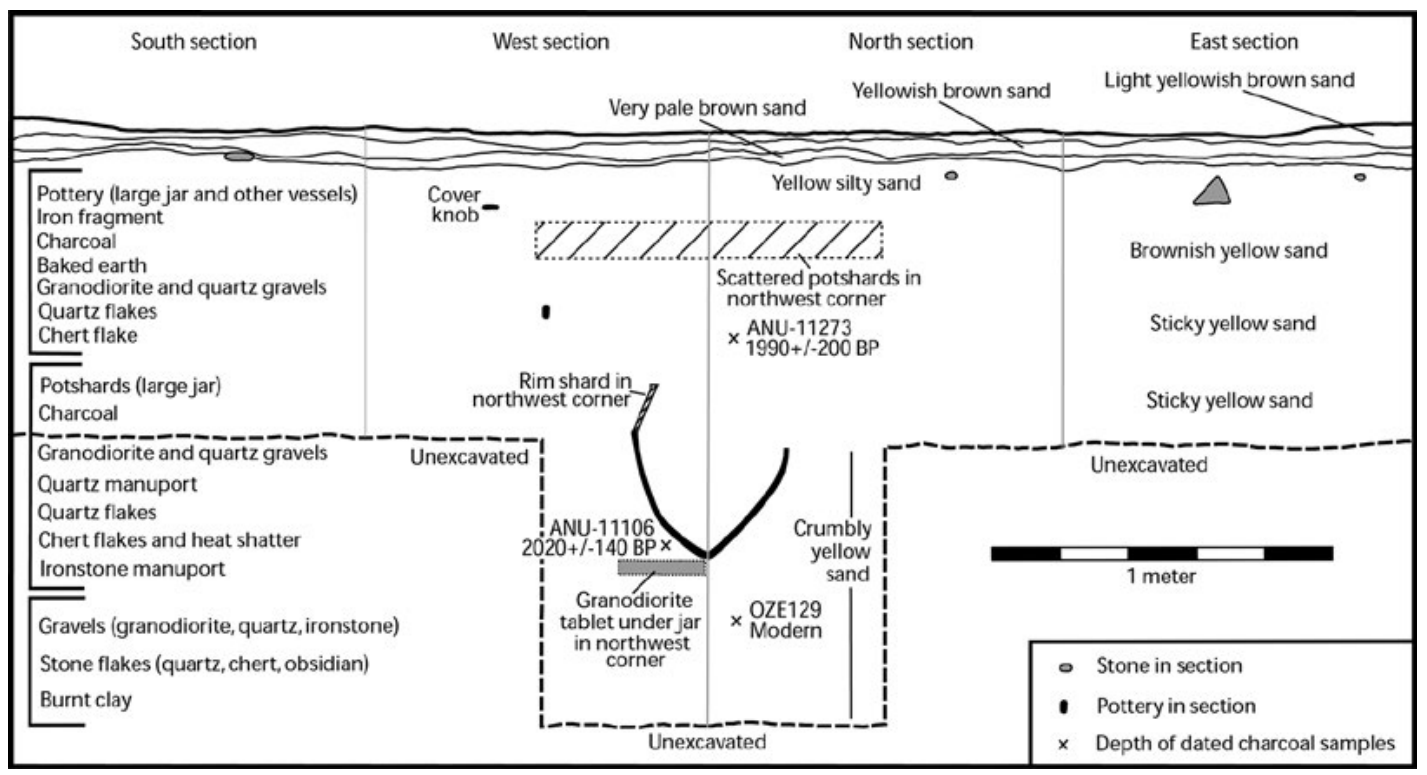

Figure 8.2 Stratigraphic section and contents of Sabbang Loang 1999 test burial jar in northwest corner.

Source: Drawn by D. Bulbeck based on excavation reports and author's laboratory studies; presented in Do 2013: Figure 20. 


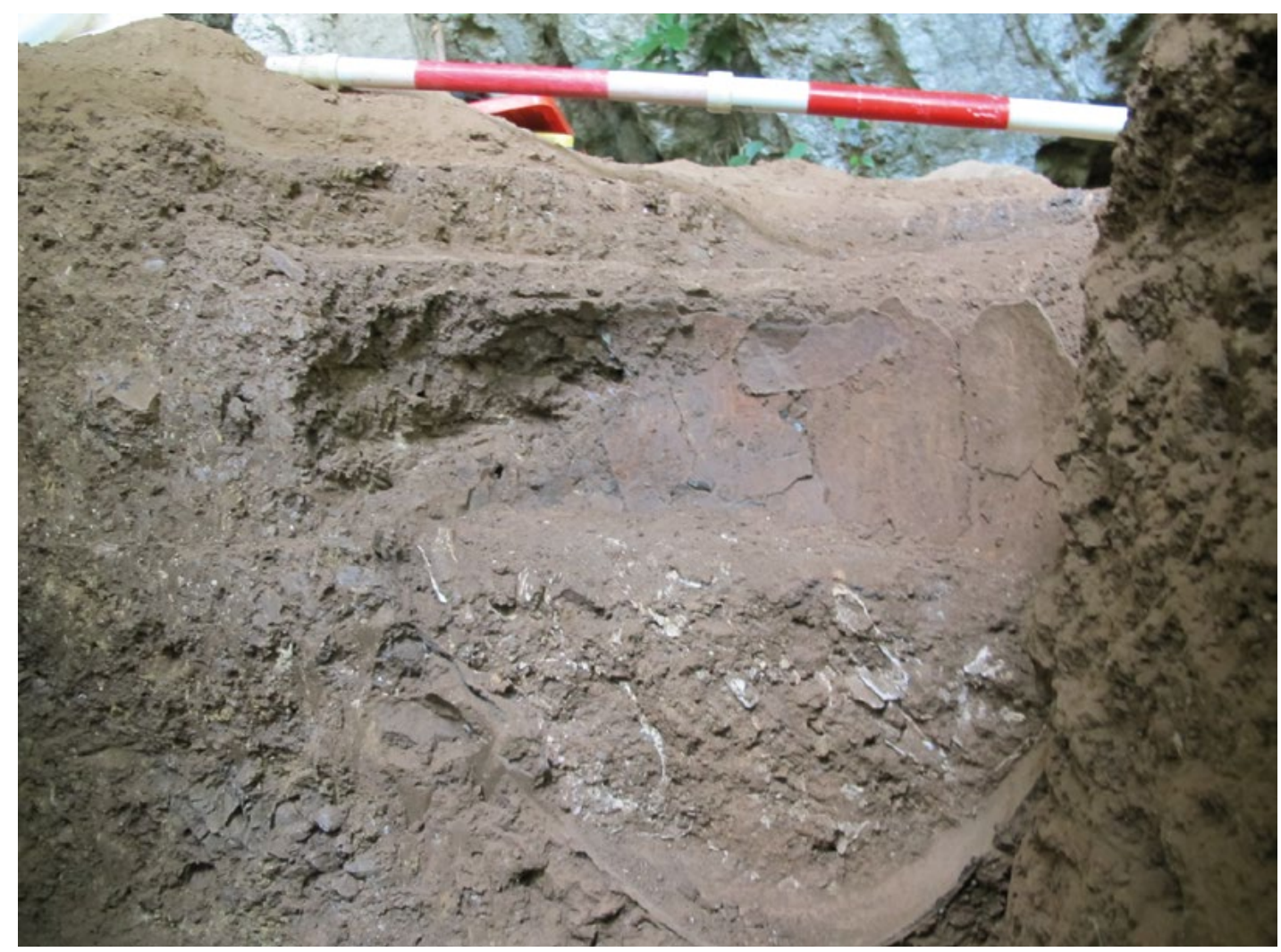

Figure 8.3 Large earthenware burial jar at Gua Lampetia sketched by Ambra Calo after its exposure in test pit.

Source: Photograph Jack Fenner, published here with his kind permission.

Lambanupa, also on Sumba, contained burial jars $30-70 \mathrm{~cm}$ in height and $20-30 \mathrm{~cm}$ in diameter, covered by an upside-down pot (as at Melolo). The interred remains included complete skeletons as well as skulls accompanied by postcranial bones, and the burial goods included pottery flasks, shells, beads and stone adzes (Bintarti 2000). Pain Haka, in Flores, is a similar site, with six jar burials including two that only contain adult skulls and others with primary infant burials and multiple burials, and rare grave goods including shell beads and a small pottery flask (Valentin et al. 2015). Lewoleba and Waibau, to the northeast, may be similar sites, with fragmentary human remains inside jars and, in the case of Lewoleba, burial goods that included shell artefacts and pottery (Bintarti 2000). Southwest Sulawesi, lying to the northwest of Nusatenggara, had highly variable mortuary practices during the Palaeometallic. These include the burial of numerous teeth with barely any associated pottery at the Leang Codong rockshelter and the direct interment of burnt and unburnt human fragments in the Leang-Leang caves of Maros (Bulbeck 19961997). Leang-Leang also has two jar-burial sites, Ulu Leang 2 and Leang Paja, that are similar to Leang Buidane. The surface collection at Ulu Leang 2 included numerous earthenware sherds interpreted as the remnants of large mortuary containers, associated with glass beads and iron fragments, and the unburnt remains of at least 50 individuals. The Leang Paja surface collection yielded medium-sized to large jars, along with ornate covers and bowls, and numerous unburnt human fragments (Flavel 1997, 2006). Open-air burial sites to the south of Leang-Leang include Takbuncinik with its suspected primary burials in large jars, Bonto Ramba with its reported association of a Heger IA bronze kettle drum alongside cremations in burial jars, and Papanlohea where a Heger IA kettle drum appears to have been used as a burial container (Table 8.4). 
Further north in Sulawesi, three burial jars were excavated at Bukit Pantaraan on the Karama River, associated with ornaments of iron, bronze, gold, glass and polished stone (no preserved human remains). The charred residues from some apparently associated potsherds date to the early to middle first millennium BC, so either the association is spurious or the date is too old (Anggraeni 2012). The three earthenware jars recovered from Pontanoa Bangka, on the northern shore of Lake Matano, stratified above a charcoal sample dating to cal. AD 900-1190, probably contained cremated human remains in association with twelfth- to fourteenth-century glass beads (Bulbeck and Caldwell 2000). In addition, a field of 11 large jars was excavated in 1938 at Sabbang Loang, where a river critical for trade with the hinterland meets the coastal plain. Re-excavations in 1998-1999 recovered an additional jar from this field of around $1 \mathrm{~m}$ high and wide (Figure 8.2) and isolated examples of similar jars across a 2 hectare area uphill from the urn field. The acidic soils explain the lack of human remains in the jars, which evidently lacked grave goods, but they can be dated to the early centuries AD based on a consistent series of five charcoal dates from the associated, Palaeometallic habitation deposits (Bulbeck and Caldwell 2000).

Table 8.5 0pen jar-burial sites from Selayar and South Sulawesi's southwest coastal plain.

\begin{tabular}{|c|c|c|}
\hline Site & Summary description of mortuary jars & Dating evidence \\
\hline $\begin{array}{l}\text { Takbuncinik, Galesong } \\
\text { (Bulbeck 1996-1997, 2010) }\end{array}$ & $\begin{array}{l}10 \text { egg-shaped jars, } 29-86 \mathrm{~cm} \text { high and } 27-58 \mathrm{~cm} \\
\text { girth, containing flexed primary burials of children } \\
\text { and adults }\end{array}$ & $\begin{array}{l}\text { Palaeometallic beads of copper and } \\
\text { semi-precious stone in separate jar }\end{array}$ \\
\hline $\begin{array}{l}\text { Manjalling, Galesong } \\
\text { (Bulbeck 1996-1997) }\end{array}$ & $\begin{array}{l}2 \text { potsherd clusters interpreted as earthenware } \\
\text { burial jar bases }\end{array}$ & 6 stone beads (Palaeometallic?) \\
\hline $\begin{array}{l}\text { Bonto Ramba } \\
\text { (Bulbeck 1996-1997) }\end{array}$ & $\begin{array}{l}\text { Low-fired sherds from reported cluster of burial jars } \\
\text { containing burnt bone }\end{array}$ & $\begin{array}{l}\text { Reported Heger IA kettle drum } \\
\text { containing necklace beads and } \\
\text { gold jewellery }\end{array}$ \\
\hline $\begin{array}{l}\text { Galoggoro, near Bonto Ramba } \\
\text { (Bulbeck 1996-1997) }\end{array}$ & $\begin{array}{l}4 \text { reported earthenware burial jars containing } \\
\text { fragmented human bone }\end{array}$ & Reported iron spearhead \\
\hline $\begin{array}{l}\text { Tile-Tile, Selayar } \\
\text { (Bulbeck 1996-1997) }\end{array}$ & $\begin{array}{l}3 \text { earthenware urns, } 1 \text { containing broken human } \\
\text { bone and grave goods }\end{array}$ & $\begin{array}{l}\text { Bronze jewellery, gold leaf, semi- } \\
\text { precious stone beads }\end{array}$ \\
\hline $\begin{array}{l}\text { Papanlohea, Selayar } \\
\text { (Bulbeck 1996-1997) }\end{array}$ & $\begin{array}{l}\text { Possible use of bronze kettle drum as burial } \\
\text { container }\end{array}$ & Heger IA kettle drum \\
\hline $\begin{array}{l}\text { Matoanging, near Galesong } \\
\text { (Bulbeck 1996-1997) }\end{array}$ & $\begin{array}{l}\text { Reported earthenware burial jars containing } \\
\text { cremated remains }\end{array}$ & $\begin{array}{l}\text { Abundant gold jewellery } \\
\text { (no imported ceramics) }\end{array}$ \\
\hline Saukang Boe (Bulbeck 1992) & $\begin{array}{l}\text { Large buried earthenware jar, reportedly containing } \\
2 \text { gold rings and iron sword, associated with a } \\
\text { cremated corpse }\end{array}$ & $\begin{array}{l}\text { AD 1500+220 (ANU-5923) on } \\
\text { human bone, cal. AD 1189-1950 }\end{array}$ \\
\hline Talaborong (Bulbeck 1992) & $\begin{array}{l}\text { Cremated human remains buried in jars, associated } \\
\text { with eleventh- to fourteenth-century Chinese } \\
\text { ceramics }\end{array}$ & $\begin{array}{l}\text { AD 1030 } \pm 170 \text { (ANU-5924) on } \\
\text { human bone, cal. AD 720-1392 }\end{array}$ \\
\hline $\begin{array}{l}\text { Bonto Lakja Selatan } \\
\text { (Bulbeck 1992) }\end{array}$ & $\begin{array}{l}\text { Cluster of Chinese martavans buried in acidic soil } \\
\text { (no extant human remains) }\end{array}$ & $\begin{array}{l}\text { Tenth to fourteenth centuries AD } \\
\text { (Chinese martavans' chronology) }\end{array}$ \\
\hline
\end{tabular}

Source: Calibration (95.4 per cent confidence interval) undertaken by the author using 0xcal 4.2 (Bronk Ramsey 2014).

In Southeast Sulawesi, excavations at Gua Lampetia cave yielded a single jar similar to the Sabbang Loang jars (Figure 8.3), but up to a millennium later, based on the thermoluminescence dates of $\mathrm{AD} 1140 \pm 60$ for the jar and $1050 \pm 120$ for the cover. The $c a .60 \mathrm{~cm}$ tall jar, which was coated with dammar tree resin, contained the commingled remains of five adult and subadult individuals, a bone pendant and a ring of marine shell from the coast. Both at Gua Lampetia and two nearby caves, there was an earlier or contemporary mortuary practice of extended inhumations (Bulbeck et al. 2016). Large earthenware mortuary jars are also reported as surface finds at the Rukuo and Anawai caves in the Matarombeo Massif to the east of Gua Lampetia, but no information has been provided as to their likely antiquity (Fage 2014). 
Southwest of Sulawesi, in the southwest corner of the archipelago, the northern beaches of Bali and Java have revealed five Palaeometallic cemeteries that evidently represent a shared tradition. These cemeteries, Pacung, Bondalem, Gilimanuk (Bali), Anyer Lor and Plawangan (Java), are distinguished by a predominance of extended inhumations and the minority presence of jar burials (Table 8.2). A sixth cemetery on the coastal plain, at Batujaya in West Java (early centuries AD), is currently documented with just nine extended inhumations (Widianto 2006), though it too may also reveal a minority presence of jar burials with future excavations.

Pacung, dated to between the late second millennium $\mathrm{BC}$ and first century $\mathrm{AD}$, includes a primary infant burial and an adult skull burial in locally made jars that had been cut to admit the human remains, and then covered with local imitations of Indian-style dishes (Calo et al. 2015). Bondalem was heavily eroded before it could be recorded, and so it is not known whether the beads and bronzes collected from the site were grave goods (Ardika 2000). At Gilimanuk, the jar burials involved secondary interments of infants, children and young adults (but no older adults) with similar Palaeometallic grave goods to the wider range documented for the Gilimanuk direct interments. The cemetery's period of use started contemporarily with Pacung but lasted till late in the first millennium AD (Aziz 2012).

Anyer Lor included two large earthenware urns, a disturbed jar that reportedly contained a primary adult burial, and a $76 \mathrm{~cm}$ tall jar $(73 \mathrm{~cm}$ girth) with a secondary adult burial and some carnelian beads (Van Heekeren 1956). At Plawangan, the burial jars were cylindrical jars measuring $22-60 \mathrm{~cm}$ tall and up to $90 \mathrm{~cm}$ in girth, including one 'double jar burial' involving two cylindrical jars stacked rim to rim. All of the jar burials were secondary, and the grave goods included beads of glass and carnelian and items of iron and bronze. The richest burial, associated with gold and earthenware pots, was interred inside a Heger IA kettle drum (Soegondho 1995). Interestingly, the use of a Heger IA kettle drum as a burial container, in this case cut open to admit the corpse, is also recorded from Manikliyu in inland Bali (Sutaba 2006).

Survey and excavation in southern Sumatra have recorded 13 open sites with earthenware burial jars and Palaeometallic grave goods. These sites have a documented chronological range between the seventh and sixteenth centuries $\mathrm{AD}$ (Table 8.5), and evidently represent a local tradition that continued into the eleventh century when megaliths started to become a prominent feature within the local settlements (Bonatz et al. 2006).

To date, jar burials have not been reported from the northern half of Sumatra nor the Thai-Malay Peninsula south of the Isthmus of Kra. However, immediately north of the Isthmus of Kra, at the northwest margin of the archipelago, Khao Sam Kaeo (KSK) yielded a burial jar with the cremated remains of two children directly dated to $260-50 \mathrm{cal}$. BC. The burial is contemporary with the main occupation phase of KSK as a massive fortified site involved in the production of ironware and glass and stone ornaments as well as the maritime trade of these and other luxury goods (Bellina-Pryce and Silapanth 2006). Presumably, the burial had been part of a larger cemetery subsequently destroyed by riverine erosion. Decorated pottery similar to that at KSK has been recovered from the disturbed mortuary cave sites of Tham Tuay (associated with a charcoal date of $156 \pm 34$ BC, Wk-3088) and Tham Pla, with closest external parallels to Hoa Diem and other Sa Huynh sites of southern coastal Vietnam (Bellina et al. 2012). The Sa Huynh culture features numerous jar burials and other mortuary disposals associated with a rich array of Palaeometallic grave goods, and marked the occupation of this stretch of Vietnam by the ancestors of the Cham, the only documented Malayo-Polynesian speakers on Mainland Southeast Asia (Dzung 2011). Thus, the mortuary sites directly north of the Isthmus of Kra may be assigned to a tradition related to coastal Vietnam. 


\section{Later mortuary jar disposals (ca. AD 1200 onwards)}

The examples covered in the previous section include traditions that continued after AD 1200, at southeastern Sabah (based on the estimated chronologies), Sumatra (Table 8.5), and the Makasar-speaking region of South Sulawesi (Saukang Boe, Talaborong and probably Bonto Lakja Selatan, Table 8.4). Makasar mortuary practices generally switched over to extended inhumations during the late pre-Islamic period between the fourteenth and seventeenth centuries, whereas their Bugis neighbours interred the cremated remains of their deceased in large imported ceramic jars, especially coarse stoneware 'martavans', as did the Wotu and Lemolang speakers at the northeast of the Bugis range (Bulbeck and Caldwell 2000; Druce et al. 2005). The Bugis practice of cremation potentially reflects cultural influence from classical Java (Bulbeck 1996-1997), but the use of jars as mortuary containers was already well established in southwest Sulawesi (Table 8.4).

Storage in caves of locally made stone mortuary jars is reported for two Kulaman Plateau sites in Mindanao. Noting an eighteenth-century coin in one of these jars, Maceda (1964) interpreted them as a continuation of an older practice of manufacturing earthenware mortuary jars. An orderly transition from Palaeometallic to later times is also evident for the mortuary jars on Fuga Island to the immediate north of Luzon. These jars were buried in the ground or in coral, or placed inside coral cairns, without grave goods (Solheim 1960). The larger jars, designed for primary disposals, included martavans as well as earthenware vessels, while both imported stoneware and earthenware jars were used as smaller containers for secondary disposals. Solheim reported an early first millennium $\mathrm{AD}$ dating for the imported jars, but such an early dating has not been repeated in later publications. As Solheim (1960) noted, the use of jars as mortuary containers could have continued till quite recently on Fuga Island, especially as the practice reportedly persisted on the Batanes until the eighteenth century.

In the Visayas, jar-burial sites postdating AD 1200 include Pilar and Banton Cave. The 24 jar burials excavated at Pilar included typically 'Palaeometallic' grave goods whereas the Banton jar burial was associated with Indian textiles (Table 8.3). In Luzon, the use of imported ceramics as mortuary containers includes thirteenth- to fourteenth-century martavans containing cremated remains at Agra and Pila (Tenazas 1968), an early Ming jar holding bone fragments at Tala (Paz et al. 2013), two sites on Cagraray Island (Fox and Evangelista 1957b) and Cabarruan in northern Luzon (Henson 1992). However, between the thirteenth century and the seventeenth century, when Christianity was widely adopted in the Philippines, direct inhumations and secondary burials in pits were the dominant mortuary disposals, with the tempayans and other high-fired, imported ceramics interred as grave goods (Clark 2013; Dueppen 2013; Sinopoli 2013).

Near Lake Towuti in Southeast Sulawesi, Grubauer (1913) recorded a recently practised tradition that involved the secondary disposal of deceased, aristocratic adults in martavans. These jars were carried in wooden litters to the same caves where the commoner adults (secondarily stored in wooden coffins) were also taken, as well as the disinterred remains of children (aristocratic and commoner) for secondary disposal. Of the numerous caves near Lake Towuti with visible remains consistent with this tradition, Gua Andomo, Gua Lampetia and Gua Sambagowala were excavated. These yielded imported ceramics dating approximately between the fifteenth and nineteenth centuries, which would appear to be the time range for the tradition, along with personal adornments such as glass beads and ornaments of bronze and brass (Bulbeck et al. 2016). This tradition is unique in Sulawesi ethnography, although the Gua Lampetia earthenware burial jar and Bugis/Wotu ceramic jar burials are potential antecedents. 
The uniqueness of the Lake Towuti tradition in Sulawesi ethnography prompted Grubauer (1913) to speculatively associate it with a tribal immigration from Borneo. Certainly, the use of martavans as mortuary containers is recorded ethnographically amongst the Ngaju of the Central Kalimantan uplands, some of the Iban of Sarawak and Sabah (Harrisson 1990), and the Kajang, Melanau, Berawan, Kelabit and Lun Dayeh of Sarawak (Winzeler 2004). In Sarawak, the jars served both as containers to hold the corpse while the soft tissues decomposed, and as the final repository where the bones were stored after collection and cleaning. The jars were then displayed either on wooden funerary monuments (Winzeler 2004) or (as recorded for the Kelabit) in rockshelters, or atop megalithic constructions, which also included stone jars holding the remains of the deceased (Lloyd-Smith et al. 2010). The chronology of this tradition based on typological dating of the jars is the sixteenth to early twentieth centuries (Harrisson 1990; Lloyd-Smith et al. 2010).

\section{Discussion and conclusions}

\section{Indo-Malaysian jar-burial horizons}

Three jar-burial horizons can be discerned for the Indo-Malaysian Archipelago. These horizons are identifiable from their rapid, initial appearance across a considerable portion of the archipelago, although in some cases they appear to have formed the basis for traditions of considerable longevity within designated parts of Indo-Malaysia.

The oldest horizon involved mortuary jars of variable size, used for primary disposals only for subadults, which co-occurred with other burial modes within the same cemetery. Neolithic examples of this horizon include Niah West Mouth in Borneo and the Manunggul A and Arku caves in the Philippines (Tables 8.1 to 8.3), as well as Teouma in Vanuatu (Valentin et al. 2015). According to Valentin et al. (2015), the cultural basis for this horizon may have been a predilection for complex mortuary rituals, which may well have emerged specifically in IndoMalaysia. Thus, recognising that certain sites represent the same horizon need not imply a single source of external influence for their shared practice of jar burials.

There is a geographic distinction between the predominantly paddle-impressed Neolithic pottery of the western archipelago (including Niah) and the frequently red-slipped Neolithic pottery of the eastern archipelago (Bulbeck 2008), which may respectively relate to early immigration of Austroasiatic speakers from Mainland Southeast Asia and Austronesian speakers from Taiwan (Simanjuntak, Chapter 1, this volume). The case for these separate origins of the Niah and Philippines jar-burial traditions is further supported by the early appearance of bronze at Niah, as noted earlier in this chapter. 


\begin{tabular}{|c|c|c|c|c|c|c|c|c|c|}
\hline 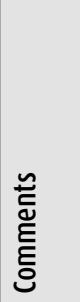 & & 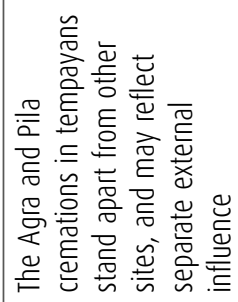 & 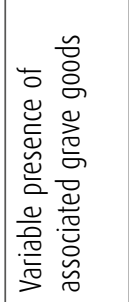 & 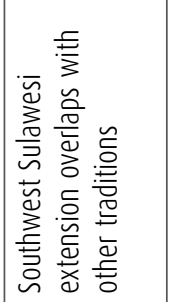 & 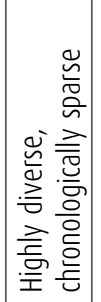 & 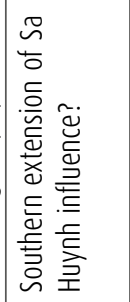 & 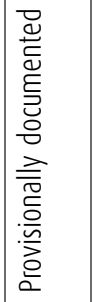 & 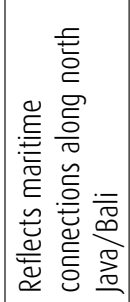 & 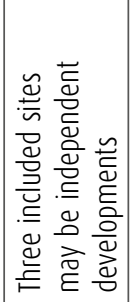 \\
\hline 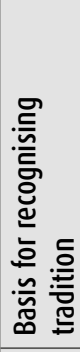 & 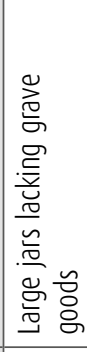 & 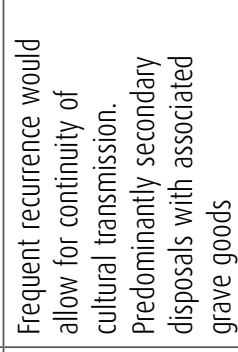 & 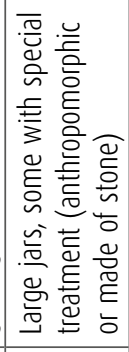 & 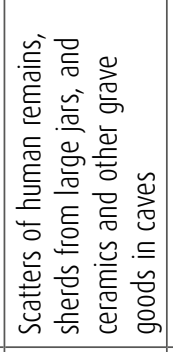 & 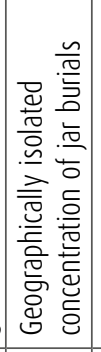 & 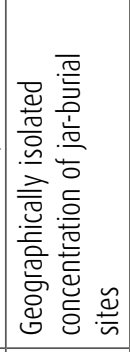 & 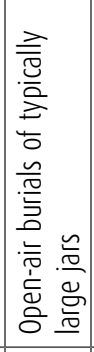 & 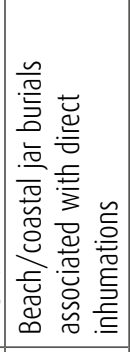 & 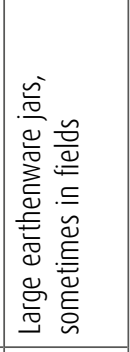 \\
\hline 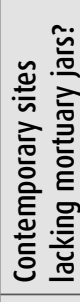 & 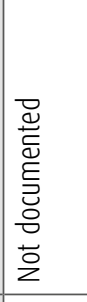 & 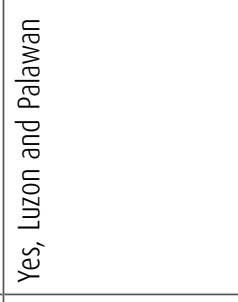 & 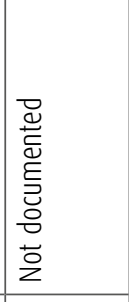 & 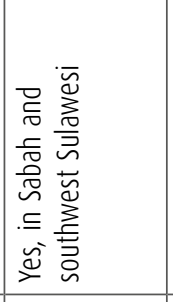 & 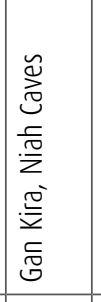 & 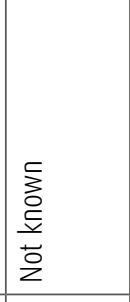 & 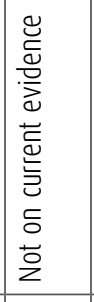 & 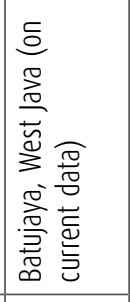 & 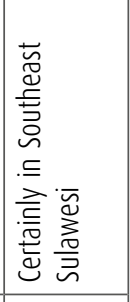 \\
\hline 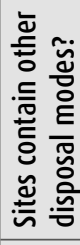 & 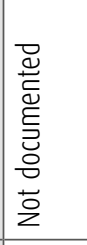 & $\begin{array}{l}\stackrel{8}{0} \\
\text { 高 } \\
\text { 茎 }\end{array}$ & 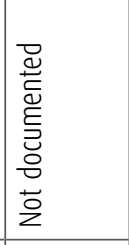 & 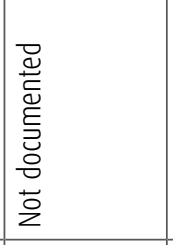 & 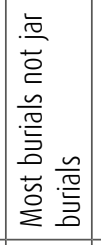 & 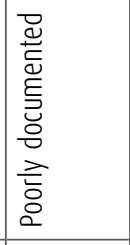 & 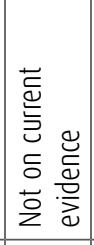 & 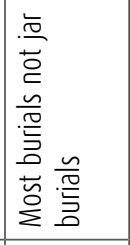 & 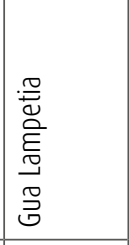 \\
\hline $\begin{array}{l}\text { 흥 } \\
\text { 응 } \\
\text { ᄒํㅡㄴ }\end{array}$ & 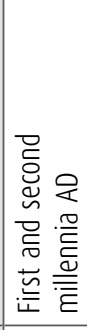 & 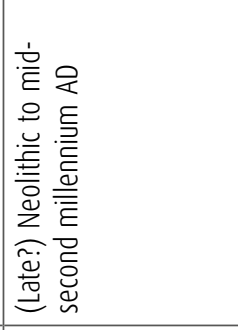 & 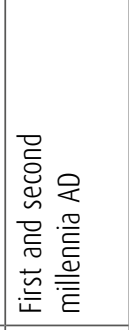 & 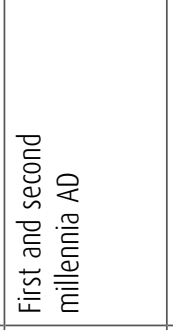 & 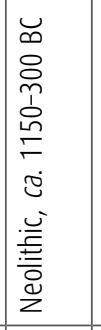 & 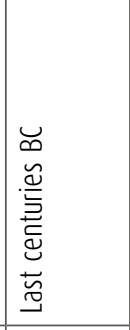 & $\begin{array}{l}8 \\
0 \\
0 \\
0 \\
0 \\
2 \\
2 \\
0 \\
0 \\
0 \\
0\end{array}$ & 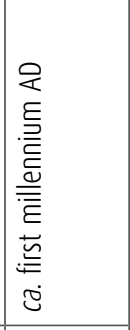 & 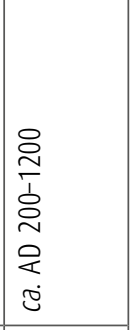 \\
\hline 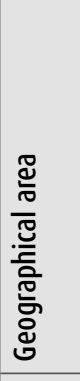 & 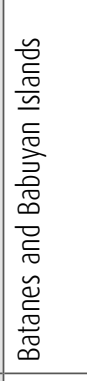 & 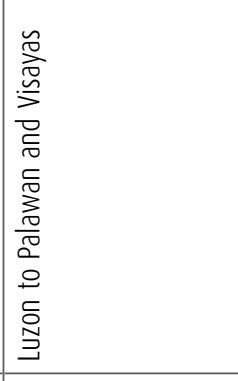 & 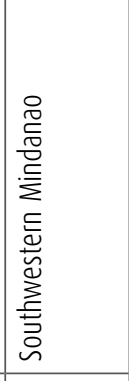 & 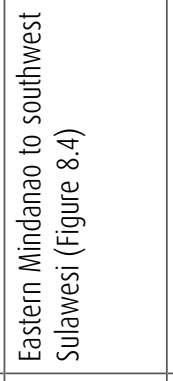 & 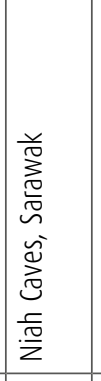 & 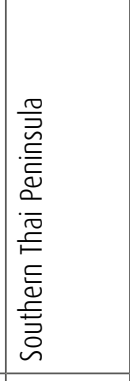 & 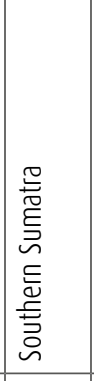 & 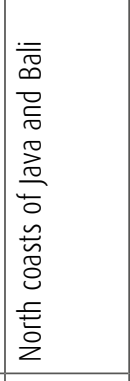 & 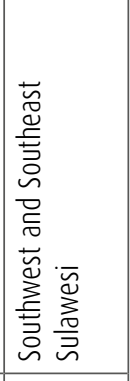 \\
\hline 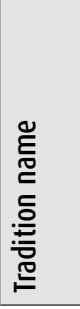 & 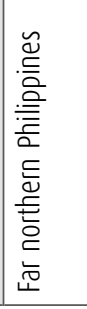 & 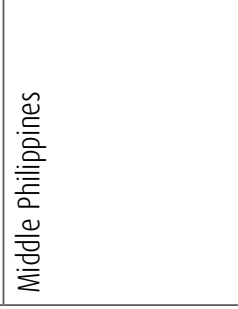 & 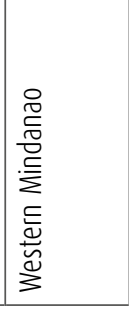 & 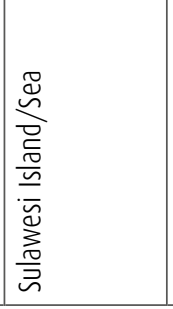 & \begin{tabular}{|l}
$\overline{\frac{\pi}{2}}$ \\
$\bar{z}$
\end{tabular} & 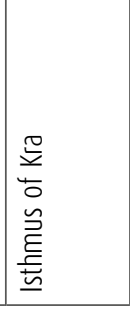 & 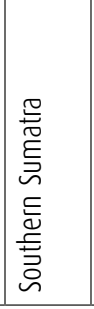 & 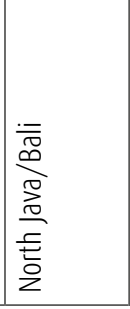 & 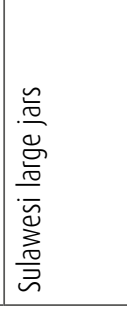 \\
\hline
\end{tabular}




\begin{tabular}{|c|c|c|c|c|c|}
\hline 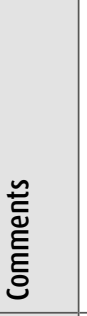 & 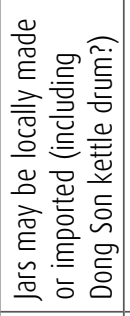 & 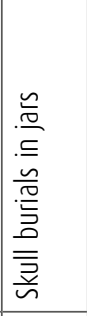 & 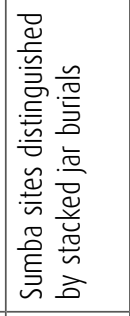 & 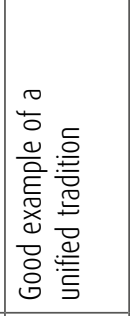 & 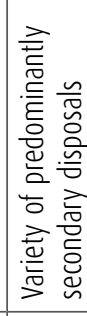 \\
\hline 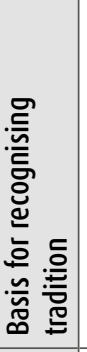 & 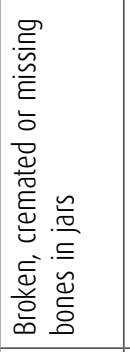 & 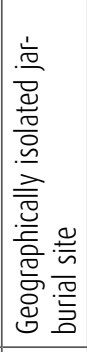 & 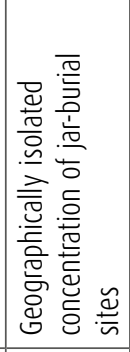 & 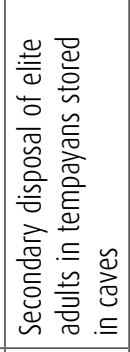 & 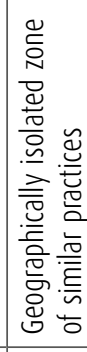 \\
\hline 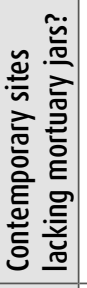 & 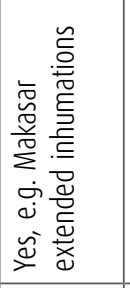 & 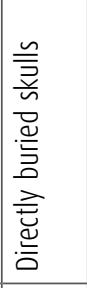 & 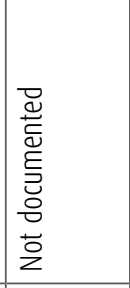 & 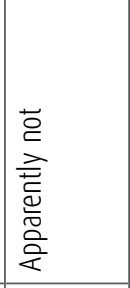 & $\cong$ \\
\hline 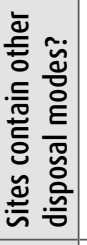 & 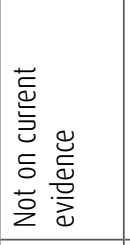 & 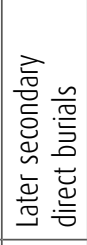 & 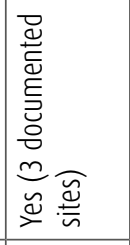 & 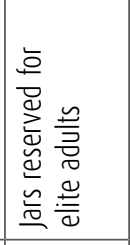 & 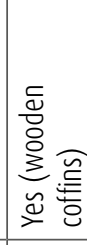 \\
\hline $\begin{array}{l}\text { वे } \\
\text { 응 } \\
\text { 은 }\end{array}$ & 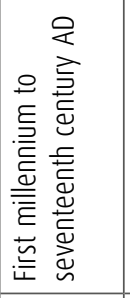 & 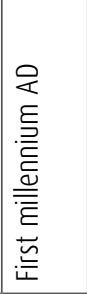 & 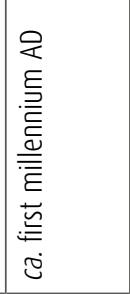 & 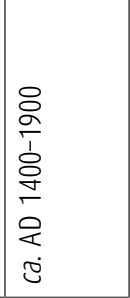 & 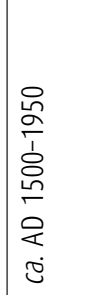 \\
\hline 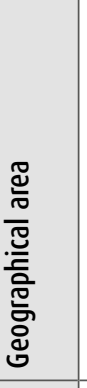 & 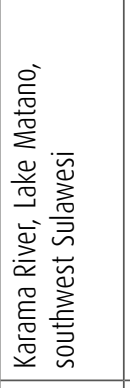 & 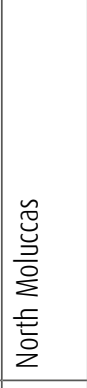 & 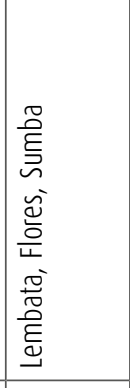 & 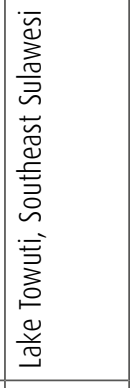 & 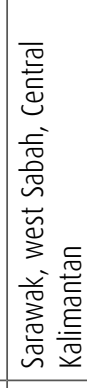 \\
\hline 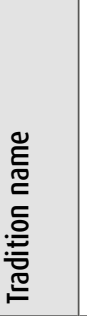 & 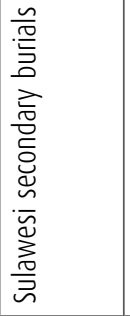 & 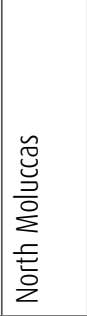 & 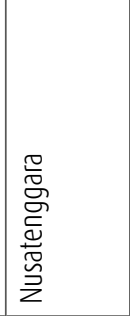 & 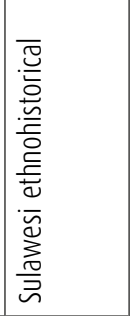 & 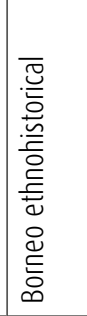 \\
\hline
\end{tabular}


The second horizon involved the specialism of large burial jars, usually of pottery, but including the use of covers and sometimes jars of stone in the southern half of the Philippines. This horizon covers sites securely dated to the early centuries AD in the Batanes Islands, Mindanao (Table 8.3) and Sulawesi (Sabbang Loang), as well as various $c a$. first millennium AD sites in the Talaud Islands (Leang Buidane), the Moluccas (Uattamdi), Sumba (Melolo and Lambanupa), and especially Sumatra (Table 8.5). The widespread distribution of this horizon corresponds well with Bellwood's (1997) overview of the Palaeometallic as a time of expanding trade linkages across the archipelago. That said, it was also a time of intensified cultural contact between the western archipelago and South Asia (e.g. Calo et al. 2015) and between the Batanes and Taiwan (Bellwood and Dizon 2013b). Accordingly, the fact that large jars dominate the jar burials of southern Sumatra and the Batanes, at opposite ends of the Archipelago, may reflect their status as independent developments inspired, respectively, by influence from South Asia and Taiwan. The case for Taiwan as the source for the Batanes large mortuary jars is strengthened by the prevailing use of the Taiwan mortuary jars for primary burials (Valentin et al. 2015).

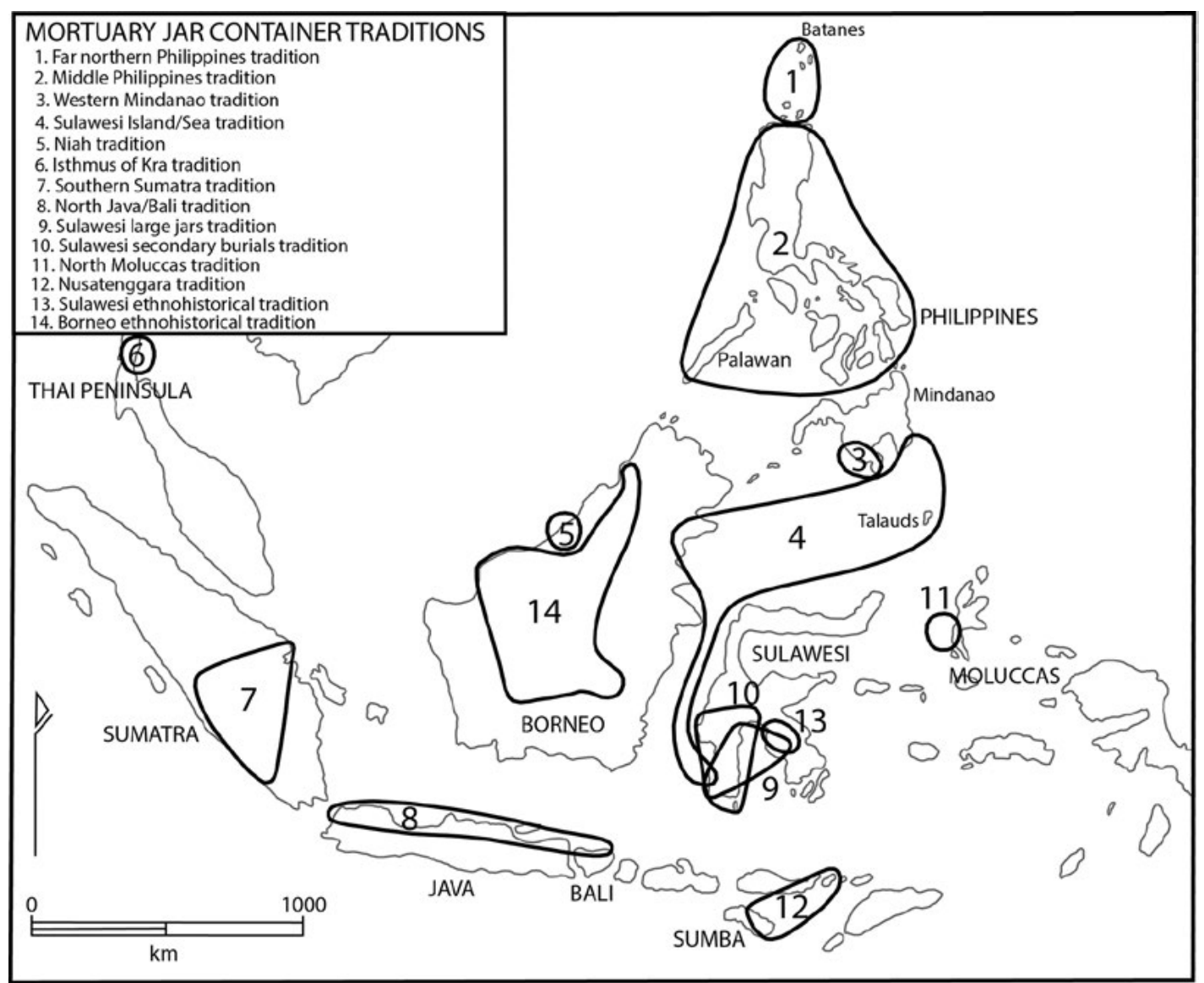

Figure 8.4 Twelve Indo-Malaysian traditions using jars as mortuary containers.

Source: Compiled and drawn by D. Bulbeck, based on Table 8.6.

The most recent horizon involved the use of large imported jars, especially martavans, for holding the cremated remains of the deceased. The geographic extent of this horizon reached from Fuga Island in the north to Borneo in the west and Sulawesi in the south. In the case of southwest Sulawesi, there appears to have been a switch from earthenware to stoneware and porcelain burial jars when the latter became readily available through maritime trade at around the fourteenth century AD (Bulbeck 1996-1997). However, in the case of Borneo, there are no immediate earthenware antecedents for the use of martavans as large mortuary containers. 


\section{Indo-Malaysian jar-burial traditions}

The preceding review of the archaeological evidence refers on several occasions to local traditions covering similar mortuary assemblages found across a definable area. These imply a strong case for cultural continuity in terms of the vertical inheritance and horizontal transmission of beliefs on the appropriate treatment of the deceased. Taking this approach to its logical conclusion, we may propose a schema of 14 traditions to cover all of the previously reviewed sites with jars used as mortuary containers (Figure 8.4, Table 8.6). The purpose of this schema is not to produce a rigid classification of the archipelago's mortuary-jar sites - other interpretations involving a smaller or larger number of traditions are certainly possible - but to illustrate that the variability is productively managed through the recognition of multiple traditions. In addition, the assignment of sites to separate traditions need not imply the absence of contacts reflected by the jar-burial horizons. For instance, haematite staining of a proportion of the Niah, Tabon and Arku Cave burials may reflect shared adoption of an ancillary mortuary practice between Sarawak and Luzon during the late Neolithic and early Palaeometallic.

The least convincing of my traditions is arguably the 'middle Philippines' tradition, recognised essentially on the basis of a reasonable likelihood of these islands' jar-burial sites tracing back to early colonisation by Austronesian speakers. In contrast, the 'Sulawesi ethnohistorical' tradition satisfies all the requirements of a tradition, being documented for numerous sites and appearing to be the only mortuary practice in operation around Lake Towuti between $c a$. AD 1500 and 1900. It evidently crossed three language groups whose common adoption of the tradition can be attributed to participation in the burgeoning local trade in dammar resin (Bulbeck et al. 2016). The 'North Java/Bali' tradition also works well as a tradition, even if one of the distinguishing features is the minority presence of jar burials in these similar cemetery sites. The shared mortuary practices can be attributed to the persistence of this coastal stretch as a node for a maritime trade network that extended to the eastern archipelago (e.g. Calo 2014). The 'Borneo ethnohistorical' tradition can also be understood in terms of a trade network, in this case the high esteem placed on imported, large ceramic jars across much of Borneo. This is a critical context for understanding the mortuary use of these jars, which were also ritually important for the fermentation of rice for festivals and strategic displays of prestige (Harrisson 1990). In addition, the appearance of jar burials in southeastern Sabah, as well as general similarities in pottery production, apparently relates to Palaeometallic interactions across the Sulawesi Sea (Bellwood 1988b), an interaction sphere suggested here to have extended to southwest Sulawesi (Figure 8.4).

\section{Cultural implications}

The Niah Neolithic cemeteries are interpreted as corporate mortuary centres where the dispersed local communities, whose subsistence basis probably depended more on foraging than farming, displayed their broader social relations through the collective burial of the deceased (LloydSmith et al. 2013). Similarly, Bonatz (2012) suggests that the Sumatra highland jar-burial sites served as ritual centres for the dispersed communities settled on the ridges to commemorate their perception of a collective ancestry in the hinterland valleys. Many of the Philippine sites would also be open to interpretation as cemeteries for the ancestors recognised by multiple communities as the basis for their corporate interests transcending the local community, although at least one site, Tumagudtad, was directly associated with a single settlement (Solheim 1960). A similar situation may apply to the southwest Sulawesi prehistoric sites, where Sabbang Loang and Galesong would appear to have been trading centres that proclaimed their independence through their jar-burial fields, whereas the communal ossuaries (including Leang Codong, which lacks mortuary jars) appear to have symbolised a collective claim to prime agricultural land (Bulbeck 2010). 
One advantage of recognising multiple traditions (Table 8.6) is the demonstration of the contrast between those where most, if not all, of the disposals of human remains were contained by jars (e.g. the southern Sumatra tradition) and those with only a small minority inside jars (e.g. the Niah and North Java/Bali traditions). Also, where jar containers were in the minority, they were sometimes associated with higher-status individuals (Niah and Sulawesi ethnohistorical traditions) and sometimes with lower-status (Arku Cave) or younger individuals (Gilimanuk). Where the deceased person was a child or reduced to fragments through preliminary mortuary rites, then the sorts of jars in common domestic use would have been large enough for deployment as mortuary containers. However, where large jars were used, these would have required considerable potting skill to be robust enough to hold their contents for the duration of the mortuary ceremony, and would have depended on sufficient personal wealth for their acquisition (especially with the imported jars). Accordingly, locally available technological skills and/or community social status may have been factors that affected whether there was no use, occasional deployment or thoroughgoing reliance on jars as mortuary containers - within a complex web of ancestorworship beliefs that would have varied greatly from place to place and time to time.

\section{Acknowledgements}

The author acknowledges the Australian Research Council for funding 'The Archaeology of Sulawesi: A Strategic Island for Understanding Modern Human Colonisation and Interactions across our Region' project (DP110101357) to Sue O'Connor, Jack Fenner, Janelle Stevenson and Ben Marwick. The Gua Lampetia burial jar was excavated and photographed (Figure 8.3) as part of this project.

\section{References}

Anggraeni. 2012. The Austronesian Migration Hypothesis as seen from Prehistoric Settlements on the Karama River, Mamuju, West Sulawesi. Unpublished PhD thesis, Department of Archaeology and Anthropology, The Australian National University, Canberra.

Anon. 2009. Early Philippine society, culture \& history. www.studymode.com/essays/Phil-Society_And_ Ci_Thulture-24113.html, viewed 25 October 2014.

Ardika, I.W. 2000. Archaeological research at Bondalem, northeastern Bali. Bulletin of the Indo-Pacific Prehistory Association 19: 81-83.

Aziz, F.A. 2012. Archaeology-demography studies at Gilimanuk site (Bali). In E. Sedyawati and I.W. Ardika (eds), Recent Studies in Indonesian Archaeology, pp. 17-48. Delhi: B.R. Publishing Corporation.

Bacus, E.A. 2004. The archaeology of the Philippine Archipelago. In I. Glover and P. Bellwood (eds), Southeast Asia from Prehistory to History, pp. 257-281. London: RoutledgeCurzon.

Barnes, R. and M. Hunt Kahlenburg (eds). 2010. The Mary Hunt Kahlenburg Collection: Five Centuries of Indonesian Textiles. Munich: DelMonico Books.

Bedford, S. and M. Spriggs. 2007. Birds on the rim: A unique Lapita carinated vessel in its wider context. Archaeology in Oceania 42: 12-21. doi.org/10.1002/j.1834-4453.2007.tb00010.x.

Bellina, B., G. Epinal and A. Favereau. 2012. Caracterisation préliminaire des poteries marqueurs d'échanges en mer de Chine méridionale à la fin de la préhistoire. Archipel 84: 7-33. doi. org/10.3406/befeo.2006.6039. 
Bellina-Pryce, B. and P. Silapanth. 2006. Weaving cultural identities on trans-Asiatic networks: Upper Thai-Malay Peninsula - an early socio-political landscape. Bulletin de l'École Française d'ÊxtremeOrient 93: 257-293.

Bellwood, P. 1976. Archaeological research in Minahasa and the Talaud islands, northeastern Indonesia. Asian Perspectives 19(2): 240-288.

- 1988a. Cultural remains in the Baturong and Madai caves. In P. Bellwood (ed.), Archaeological Research in South-Eastern Sabah, pp. 128-131. Kota Kinabalu: Sabah Museum Monograph vol. 2.

- 1988b. Madai and Baturong since 1000BC: Comparative perspectives and cultural trends. In P. Bellwood (ed.), Archaeological Research in South-Eastern Sabah, pp. 245-258. Kota Kinabalu: Sabah Museum Monograph vol. 2.

. 1988c. The prehistoric earthenwares and other small finds of the Atas and Idahan periods. In P. Bellwood (ed.), Archaeological Research in South-Eastern Sabah, pp. 173-244. Kota Kinabalu: Sabah Museum Monograph vol. 2.

1997. Prehistory of the Indo-Malaysian Archipelago. 2nd edition. Honolulu: University of Hawaii Press.

Bellwood, P. and E. Dizon. 2013a. Archaeological investigations at Savidug, Sabtang Island. In P. Bellwood and E. Dizon (eds), 4000 Years of Migration and Cultural Exchange: The Archaeology of the Batanes Islands, Northern Philippines, pp. 47-65. Terra Australis 40. Canberra: ANU E Press.

. 2013b. The Batanes Islands and the prehistory of Island Southeast Asia. In P. Bellwood and E. Dizon (eds), 4000 Years of Migration and Cultural Exchange: The Archaeology of the Batanes Islands, Northern Philippines, pp. 235-241. Terra Australis 40. Canberra: ANU E Press.

Bellwood, P., N. Goenadi, G. Irwin, A.W. Gunadi and D. Tanudirjo. 1998. 35,000 years of prehistory in the northern Moluccas. In G-J. Bartstra (ed.), Bird's Head Approaches, pp. 233-275. Modern Quaternary Research in Southeast Asia 15. Rotterdam: A.A. Balkema.

Bintarti, D.D. 2000. More on urn burials in Indonesia. Bulletin of the Indo-Pacific Prehistory Association 19: 73-77.

Bonatz, D. 2012. A highland perspective on the archaeology and settlement history of Sumatra. Archipel 84: 35-81.

Bonatz, D., J.D. Neidel and M.L. Tjoa-Bonatz. 2006. The megalithic complex of highland Jambi: An archaeological perspective. Bijdragen tot de Taal-, Land-en Volkenkunde 162(4): 490-522. doi. org/10.1163/22134379-90003664.

Bronk Ramsey, C. 2014. Oxcal 4.2 manual. c14.arch.ox.ac.uk/oxcal.html.

Bulbeck, F.D. 1992. A Tale of Two Kingdoms: The Historical Archaeology of Gowa and Tallok, South Sulawesi, Indonesia. Unpublished PhD thesis, Department of Archaeology and Anthropology, The Australian National University, Canberra.

. 1996-1997. The Bronze-Iron Age of South Sulawesi, Indonesia: mortuary traditions, metallurgy and trade. In F.D. Bulbeck and N. Barnard (eds), Ancient Chinese and Southeast Asian Bronze Age Cultures vol. II, pp. 1007-1076. Taipei: Southern Materials Center Inc.

- 2008. An integrated perspective on the Austronesian diaspora: the switch from cereal agriculture to maritime foraging in the colonisation of Island Southeast Asia. Australian Archaeology 67: 31-51. doi.org/10.1080/03122417.2008.11681877. 
2010. Uneven development in southwest Sulawesi, Indonesia during the Early Metal Phase. In B. Bellina, E.A. Bacus, T.O. Pryce and J. Wisseman Christie (eds), 50 Years of Archaeology in Southeast Asia: Essays in Honour of Ian Glover, pp. 152-169. Bangkok: River Books.

2011. Biological and cultural evolution in the population and culture history of Malaya's anatomically modern inhabitants. In N. Enfield (ed.), Dynamics of Human Diversity: The Case of Mainland Southeast Asia, pp. 207-255. Pacific Linguistics 627. Canberra: The Australian National University.

- Submitted. Bioarchaeological analysis of the Northern Moluccan excavated human remains. For P. Bellwood (ed.), Archaeology in the Northern Moluccas, Indonesia.

Bulbeck, D. and I. Caldwell. 2000. Land of Iron: The Historical Archaeology of Luwu and the Cenrana Valley. Hull: University of Hull Centre for South-East Asian Studies.

Bulbeck, D., F.A. Aziz, S. O'Connor, A. Calo, J.N. Fenner, B. Marwick, J. Feathers, R. Wood and S. Prastiningtyas. 2016. Mortuary caves and the dammar trade in the Towuti-Routa region, Sulawesi, in an Island Southeast Asian context. Asian Perspectives 55(2): 148-183. doi.org/10.1353/ asi.2016.0017.

Calo, A. 2014. Trails of Bronze Drums across Early Southeast Asia - Exchange Routes and Connected Cultural Spheres. Singapore: Institute of Southeast Asian Studies.

Calo, A., B. Prasetyo, P. Bellwood, J.W. Lankton, B. Gratuze, T.O. Pryce, A. Reinecke, V. Leusch, H. Schenk, R. Wood, R.A. Bawono, I.D.K. Gede, N.L.K.C. Yuliati, J. Fenner, C. Reepmeyer, C. Castillo and A. Carter. 2015. Sembiran and Pacung on the northern coast of Bali: A strategic crossroads for early trans-Asiatic exchange. Antiquity 344: 378-396. doi.org/10.15184/aqy.2014.45.

Clark, J.L. 2013. The distribution and cultural context of artificial cranial modification in the central and southern Philippines. Asian Perspectives 52(1): 28-42. doi.org/10.1353/asi.2013.0003.

Coutts, P.J. 1983. An Archaeological Perspective of Panay Island, Philippines. Cebu City: University of San Carlos.

Crane, H.R. and J.B. Griffin. 1959. University of Michigan radiocarbon dates IV. Radiocarbon 1: 173-198. doi.org/10.1017/s0033822200020452.

Cuevas, N. and A. de Leon. 2008. Archaeological investigations of Sagel Cave at Maitum, Sarangani Province, Southern Mindanao, Philippines. Hukay 13: 1-24.

Do, M. 2013. Iron-Nickel Smelting Production in Luwu, South Sulawesi during the pre-Islamic Period. Unpublished MSc dissertation, Institute of Archaeology, University College of London. Available at: www.oxis.org/theses/misol-2103.pdf.

Druce, S., D. Bulbeck and I. Mahmud. 2005. A transitional Islamic Bugis cremation in Bulubangi, South Sulawesi: Its historical and archaeological context. Review of Indonesian and Malaysian Affairs 39(1): $1-22$.

Dueppen, S. 2013. Temporal variability in Southeast Asian dragon jars: A case from the Philippines. Asian Perspectives 52(1): 75-118. doi.org/10.1353/asi.2013.0004.

Dzung, L.T.M. 2011. Central Vietnam during the period from 555 BCE to CE 500. In P.-Y. Manguin, A. Mani and G. Wade (eds), Early Interactions between South and Southeast Asia: Reflections of CrossCultural Exchange, pp. 17-45. Singapore: Institute of Southeast Asian Studies.

Fagan, B. 1994. In the Beginning: Introduction to Archaeology. 8th edition. New York: HarperCollins. 
Fage, L.-H. 2014. Rapport préliminaire: prospection archéologique Massif de Matarombeo, Sulawesi Central, octobre 2014. kalimanthrope.com/sulawesi2014/RAPPORT\%20SULAWESI-2014-OK. pdf, viewed 24 June 2015.

Flavel, A. 1997. Sa-Huynh Kalanay? Analysis of the Prehistoric Decorated Earthenware of South Sulawesi in an Island Southeast Asian Context. Unpublished BSc (Hons) thesis, Centre for Archaeology, University of Western Australia, Perth.

2006. Sa-Huynh Kalanay: Analysis of the prehistoric decorated earthenware of South Sulawesi in an Island Southeast Asian context. In W.G. Solheim II and contributors, Archaeology and Culture in Southeast Asia: Unravelling the Nusantao, pp. 193-237. Quezon City: University of Philippines Press.

Fox, R. 1970. The Tabon Caves. Manila: Monographs of the National Museum 1.

Fox, R. and A. Evangelista. 1957a. The Bato Caves, Sorsogon Province, Philippines: A preliminary report of a jar burial-stone tool assemblage. Journal of East Asiatic Studies 6(1): 49-56.

1957b. The cave archaeology of Cagraray Island, Albay Province, Philippines: A preliminary report of exploration and excavations. Journal of East Asiatic Studies 6(1): 57-68.

Grubauer, A. 1913. Unter Kopfjägern in Central-Celebes: Ethnologische Streifzüge in Sudost-und CentralCelebes. Leipzig: R. Voigtlander.

Guillaud, D., H. Forestier, A. Romsan and B. Prasetyo. 2006. Bab 2-Daerah pengunungan: Sebuah pendekatan arkeogeografis untuk mengetengahkan zaman protosejarah. In D. Guillaud (ed.), Menyelusuri Sungai, Menurut Waktu: Penelitian Arkeologi di Sumatera Selatan, pp. 35-47. Jakarta: Pusat Penelitian Arkeologi Nasional Paris: Institut de Recherche pour le Développement.

Harrisson, B. 1958. Niah's Lobang Tulang ('Cave of Bones'). Sarawak Museum Journal 8 (n.s. 12): 596-610.

- 1967. A classification of Stone Age burials from Niah Great Cave, Sarawak. Sarawak Museum Journal 15 (n.s. 30-31): 126-200.

—. 1990. Pusaka: Heirloom Jars of Borneo. Singapore: Oxford University Press.

Henson, F.G. 1992. Jar burial excavations in the Philippines. In I. Glover, P. Suchitta and J. Villiers (eds), Early Metallurgy, Trade and Urban Centres in Thailand and Southeast Asia, pp. 213-225. Bangkok: White Lotus.

Higham, C. 2011. The Bronze Age of Southeast Asia: New insight on social change from Ban Non Wat. Cambridge Archaeological Journal 21: 365-389. doi.org/10.1017/S0959774311000424.

Kress, J.H. 2004. The necrology of Sa'gung rockshelter and its place in Philippine prehistory. In V. Paz (ed.), Southeast Asian Archaeology Wilhelm G. Solheim II Festschrift, pp. 239-275. Quezon City: University of the Philippines Press.

Lloyd-Smith, L. and F. Cole. 2010. The jar-burial tradition in the West Mouth of Niah Cave, Sarawak. In B. Bellina, E.A. Bacus, T.O. Pryce and J. Wisseman Christie (eds), 50 Years of Archaeology in Southeast Asia: Essays in Honour of Ian Glover, pp. 114-127. Bangkok: River Books.

Lloyd-Smith, L., G. Barker, H. Barton, I. Datan, C. Gosden, B. Nyíri, M. Janowski and E. Preston. 2010. The Cultured Rainforest project: Archaeological investigations in the third (2009) season of fieldwork in the Kelabit highlands of Sarawak. Sarawak Museum Journal 67 (88): 57-104. 
Lloyd-Smith, L., G. Barker, H. Barton, J. Cameron, F. Cole, P. Daly, C. Doherty, C. Hunt, J. Krigbaum, H. Lewis, J. Manser, V. Paz, P.J. Piper, R.J. Rabett, G. Rushworth and K. Szabó. 2013. 'Neolithic' societies c. 4000-2000 years ago: Austronesian farmers? In G. Barker (ed.), Rainforest Foraging and Farming in Island Southeast Asia: The Archaeology of the Niah Caves, Sarawak, vol. 1, pp. 255-298. Cambridge: McDonald Institute for Archaeological Research.

Maceda, M.N. 1964. Preliminary report on ethnographic and archaeological field work in the Kulaman Plateau, Island of Mindanao, Philippines. Anthropos 59: 75-82.

Mijares, A.S.B. 2005. The archaeology of the Peñablanca cave sites, northern Luzon, Philippines. Journal of Austronesian Studies 1(2): 65-93.

Ogawa, H. 2004. Chronological context of nondecorated black pottery phase from Lal-lo shell middens, Cagayan Province, Philippines. In V. Paz (ed.), Southeast Asian Archaeology Wilhelm G. Solheim II Festschrift, pp. 184-208. Quezon City: University of the Philippines Press.

Paz, V., A. Ragragio and J. Medrana. 2013. Preliminary archaeological survey of the Municipality of Catanauan, Bondoc Peninsula, Quezon Province. catanauanproject.com/index.php/publications/ finish/255-catanauan-site-reports/1691-preliminary-archaeological-survey-of-the-municipality-ofcatanauan-bondoc-peninsula-quezon-province/, viewed 15 November 2014.

Piper, P.J., F.Z. Campos and H.-c. Hung. 2009. A study of the animal bone recovered from pits 9 and 10 at the site of Nagsabaran in northern Luzon, Philippines. Hukay 14: 47-90.

Ronquillo, W. 2003. Philippine earthenware pottery from the early prehistoric period. In M. John (ed.), Earthenware in Southeast Asia, pp. 32-38. Singapore: Singapore University Press.

Sinopoli, S.M. 2013. New research on an old collection: Studies of the Philippine Expedition ('Guthe') Collection of the Museum of Anthropology, University of Michigan. Asian Perspectives 52(1): 1-11. doi.org/10.1353/asi.2013.0000.

Soegondho, S. 1995. Tradisi Gerabah di Indonesia. Jakarta: Himpunan Keramik Indonesia.

Soeroso, M. 1997. Recent discoveries of jar burials in South Sumatra. Bulletin de l'École française d'Extrême-Orient 84: 418-422. doi.org/10.3406/befeo.1997.3825.

Solheim, W.G. II. 1960. Jar burial in the Babuyan and Batanese Islands and in Central Philippines, and its relationship to jar burial elsewhere in the Far East. Philippine Journal of Science 8-9: 115-148.

Solheim, W.G. II, A.M. Legaspi and J.S. Neri. 1979. Archaeological Survey in Southeastern Mindanao. Monograph no. 8. Manila: National Museum of the Philippines.

Spriggs, M. 1989. The dating of the Island Southeast Asian Neolithic: An attempt at chronometric hygiene and linguistic correlation. Antiquity 63: 587-613. doi.org/10.1017/S0003598X00076560.

Sutaba, I.M. 2006. Recently discovered burial systems at Manikliyu, Bali. In T. Simanjuntak, M. Hisyam, B. Prasetyo and T.S. Nastiti (eds), Archaeology: Indonesian Perspective, R.P. Soejono's Festschrift, pp. 303-316. Jakarta: Indonesian Institute of Science.

Szabó, K. and H. Ramirez. 2009. Worked shell from Leta Leta Cave, Palawan. Archaeology in Oceania 44: 150-159. doi.org/10.1002/j.1834-4453.2009.tb00059.x.

Szabó, K., M.C. Swete Kelly and A. Peñalosa. 2004. Preliminary results from excavations in the eastern mouth of Ille Cave, northern Palawan. In V. Paz (ed.), Southeast Asian Archaeology Wilhelm G. Solheim II Festschrift, pp. 209-224. Quezon City: University of the Philippines Press. 
Szabó, K., F. Cole, L. Lloyd-Smith, G. Barker, C. Hunt, P.J. Piper and C. Doherty. 2013. The 'Metal Age' at the Niah Caves, c. 2000-500 years ago. In G. Barker (ed.), Rainforest Foraging and Farming in Island Southeast Asia: The Archaeology of the Niah Caves, Sarawak, vol. 1, pp. 288-340. Cambridge: McDonald Institute for Archaeological Research.

Tenazas, R.C.P. 1968. A Report on the Archaeology of the Locsin-University of San Carlos Excavations in Pila, Laguna. books.google.com.au/books/about/A_Report_on_the_Archaeology_of_the_Locsi. html?id=M3ZzPQAACAAJ\&redir_esc=y, viewed 2 October 2015.

Thiel, B. 1986-1987. Excavations at Arku Cave, Northeast Luzon, Philippines. Asian Perspectives 28(1): 61-81.

Tjoa-Bonatz, M.L. 2012. More than 3400 years of earthenware traditions in highland Jambi on Sumatra. In M.L. Tjoa-Bonatz, A. Reinecke and D. Bonatz (eds), Connecting Empires and States: Selected Papers from the 13th International Conference of the European Association of Southeast Asian Archaeologists, vol. 2, pp. 16-31. Singapore: National University of Singapore Press.

Van Heekeren, H.R. 1956. Note on a proto-historic urn-burial site at Anjar, Java. Anthropos 51: 194-201. 1972. The Stone Age of Indonesia. 2nd edition. Verhandelingen van het Koninklijk Instituut voor Taal-, Land- en Volkenkunde 61. The Hague: Martinus Nijhoff.

Valentin, F., J.-i. Choi, H. Lin, S. Bedford and M. Spriggs. 2015. Three-thousand-year-old jar-burials at the Teouma cemetery (Vanuatu): A Southeast Asian-Lapita connection? In C. Sand, S. Chiu and N. Hogg (eds), The Lapita Cultural Complex in Time and Sapce: Expansion Routes, Chronologies and Typologies, pp. 81-101. Noumea: Institut d'archéologie de la Nouvelle-Calédonie et du Pacifique.

Widianto, H. 2006. Cranio-morphological aspects of the recent discovery of human remains from Batujaya, West Java. In T. Simanjuntak, M. Hisyam, B. Prasetyo and T.S. Nastiti (eds), Archaeology: Indonesian Perspective, R.P. Soejono's Festschrift, pp. 124-135. Jakarta: Indonesian Institute of Science.

Winters, N.J. 1974. An application of dental anthropological analysis to the human dentition of two Early Metal Age sites, Palawan, Philippines. Asian Perspectives 17(1): 28-35.

Winzeler, R.L. 2004. The Architecture of Life and Death in Borneo. Honolulu: University of Hawai'i Press. 
This text is taken from New Perspectives in Southeast Asian and Pacific Prehistory, edited by Philip J. Piper, Hirofumi Matsumura and David Bulbeck, published 2017 by ANU Press, The Australian National University, Canberra, Australia. 